
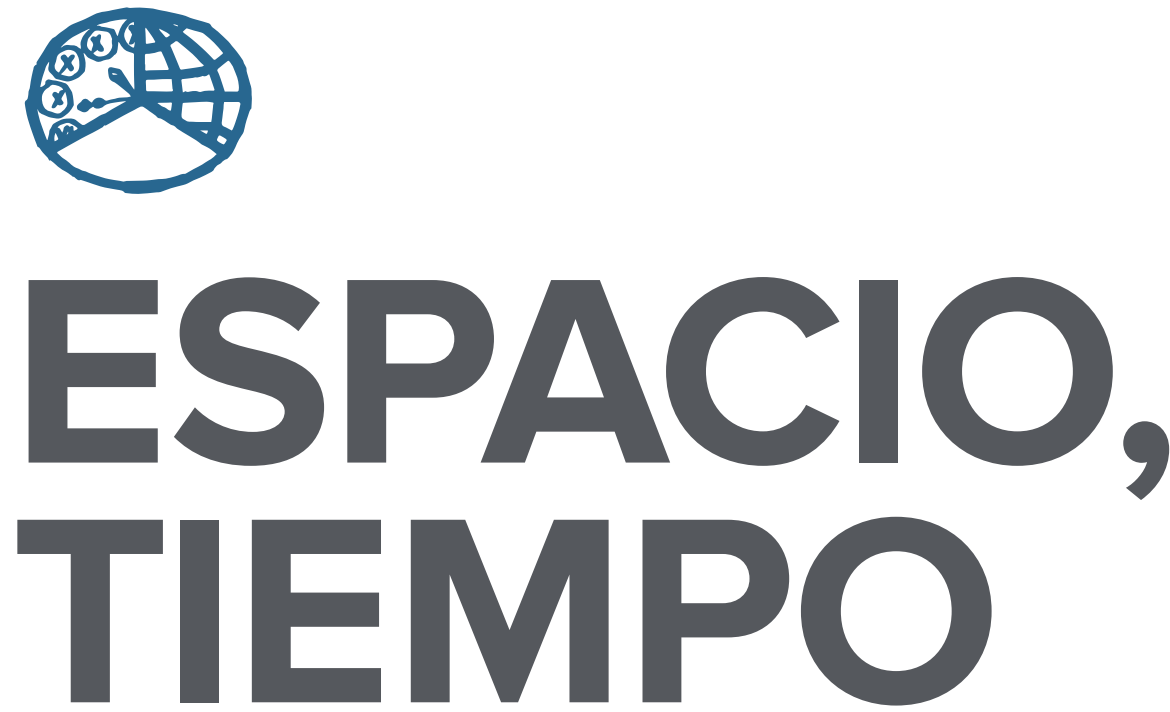

AÑO 2019 NUEVA ÉPOCA ISSN 1130-4715

E-ISSN 2340-1478
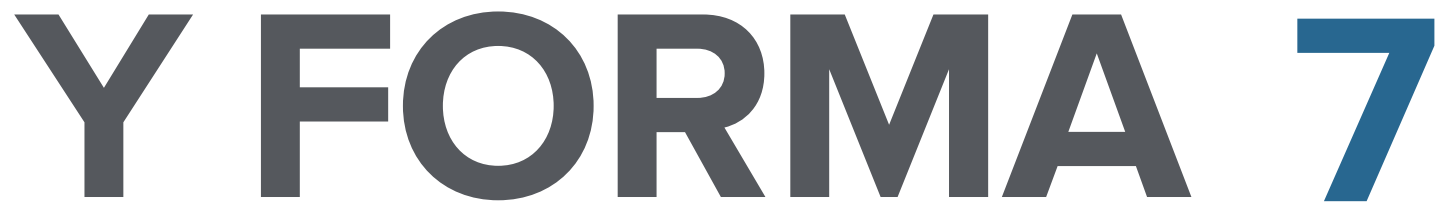

SERIE VII HISTORIA DEL ARTE

REVISTA DE LA FACULTAD DE GEOGRAFÍA E HISTORIA 


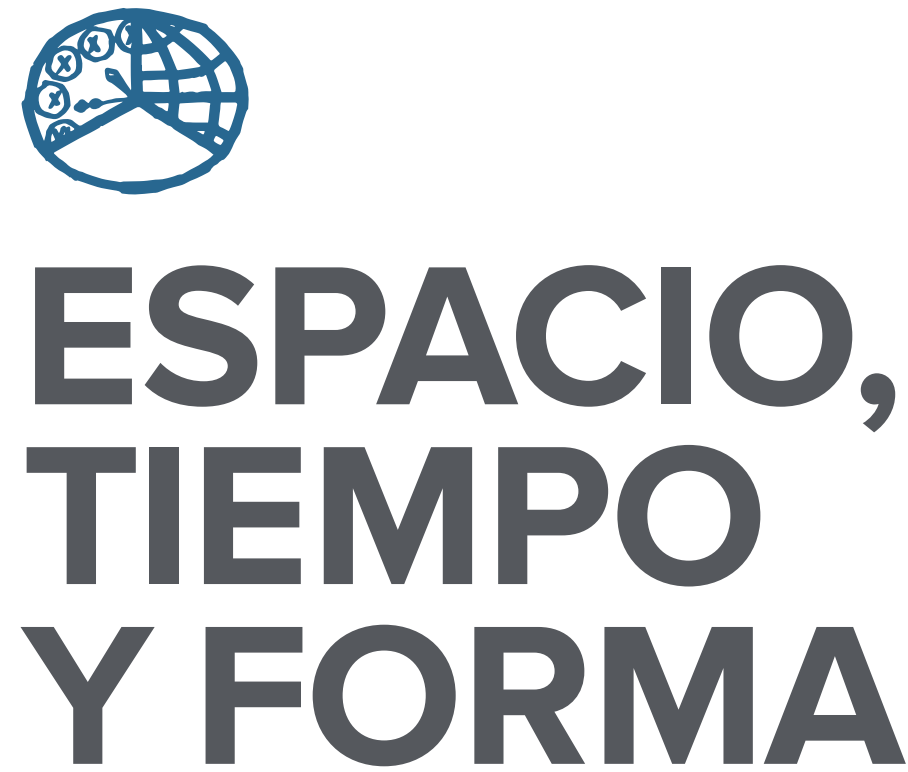

AÑO 2019

NUEVA ÉPOCA

ISSN $1130-4715$

E-ISSN 2340-1478

SERIE VII HISTORIA DEL ARTE

REVISTA DE LA FACULTAD DE GEOGRAFİA E HISTORIA

DOI: http://dx.doi.org/10.5944/etfvii.7.2019

\section{UกED}

UNIVERSIDAD NACIONAL DE EDUCACIÓN A DISTANCIA 
La revista Espacio, Tiempo y Forma (siglas recomendadas: ETF), de la Facultad de Geografía e Historia de la UNED, que inició su publicación el año 1988, está organizada de la siguiente forma:

$$
\begin{aligned}
& \text { SERIE I - Prehistoria y Arqueología } \\
& \text { SERIE II - Historia Antigua } \\
& \text { SERIE III - Historia Medieval } \\
& \text { SERIE IV - Historia Moderna } \\
& \text { SERIE V - Historia Contemporánea } \\
& \text { SERIE VI - Geografía } \\
& \text { SERIE VII - Historia del Arte }
\end{aligned}
$$

Excepcionalmente, algunos volúmenes del año 1988 atienden a la siguiente numeración:

$$
\begin{aligned}
& \mathrm{N}^{\circ} 1 \text { - Historia Contemporánea } \\
& \mathrm{N}^{\circ} 2 \text { - Historia del Arte } \\
& \mathrm{N}^{\circ} 3 \text { - Geografía } \\
& \mathrm{N} .^{\circ} 4 \text { - Historia Moderna }
\end{aligned}
$$

ETF no se solidariza necesariamente con las opiniones expresadas por los autores.

UNIVERSIDAD NACIONAL DE EDUCACIÓN A DISTANCIA

Madrid, 2019

SERIE VII · HISTORIA DEL ARTE (NUEVA ÉPOCA) N..$^{\circ} 72019$

ISSN $1130-4715 \cdot$ E-ISSN 2340-1478

DEPÓSITO LEGAL

$M-21.037-1988$

URL

ETF VII · HISTORIA DEL ARTE $\cdot$ http://revistas.uned.es/index.php/ETFVII

DISEÑO Y COMPOSICIÓN

Carmen Chincoa Gallardo · http://www.laurisilva.net/cch

Impreso en España · Printed in Spain 


\section{DOSSIER}

L'APELLE VITRUVIANO: RIFLESSIONI SULLA CULTURA ARCHITETTONICA DEI PITTORI NELLA PRIMA ETÃ MODERNA

Edito da Filippo Camerota

THE VITRUVIAN APELLES: THOUGHTS ON

THE ARCHITECTURAL CULTURE OF PAINTERS

IN THE EARLY MODERN AGE

Edited by Filippo Camerota

EL APELLES VITRUVIANO: REFLEXIONES EN TORNO

A LA CULTURA ARQUITECTÓNICA DE LOS PINTORES

DE LA EDAD MODERNA

Editado por Filippo Camerota 


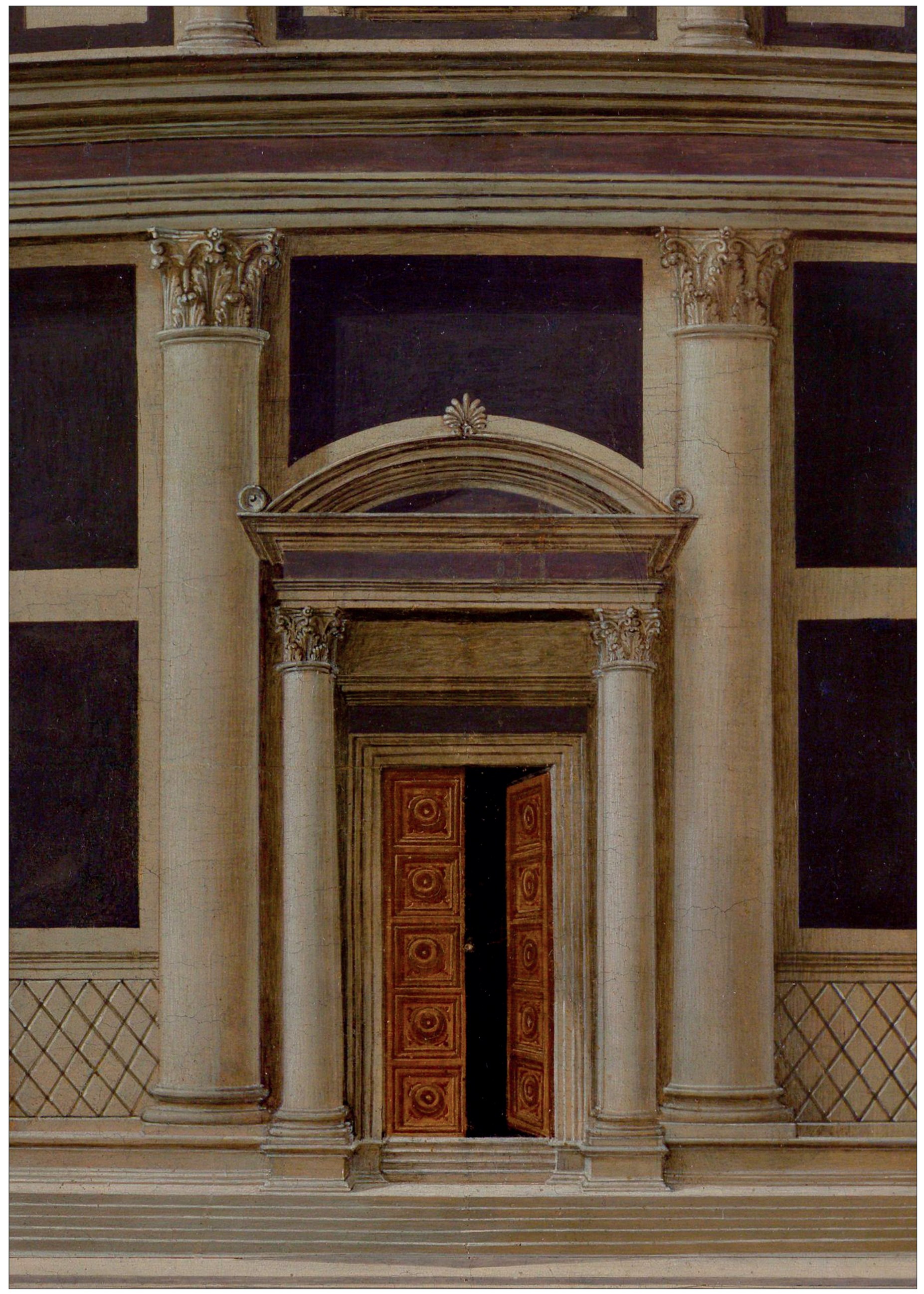




\title{
METAESCENOGRAFÍAS PINTADAS
}

\section{PAINTED META-SCENOGRAPHIES}

\author{
Carmen González-Román ${ }^{1}$ \\ Doi: http://dx.doi.org/10.5944/etfvii.2019.24267
}

\section{Resumen}

La vista urbana en perspectiva ilusionista es un motivo iconográfico procedente de la cultura visual del Renacimiento italiano, momento en el que fue utilizado tanto en el teatro como en la pintura. Este artículo estudia la influencia y pervivencia de esta iconografía en la pintura occidental y pone en evidencia, particularmente, los casos de metaescenografías. Se plantea una reflexión sobre los usos de dicho motivo, en especial, su empleo como recurso metaartístico, sus variantes, así como su temporalidad. A partir de ahí, se analizan algunos ejemplos de las vanguardias artísticas del siglo XX donde esta iconografía reaparece, bien constatando la supervivencia de la visión euclidiana o adquiriendo el significado de metaescenografías pintadas.

Palabras clave

Perspectiva; escenografía; metaescenografía; metapintura.

\section{Abstract}

The urban view in an illusionist perspective is an iconographic motif from the visual culture of the Italian Renaissance, at which time it was used both in theatre and in painting. This article studies the influence and survival of this iconography in Western painting and highlights, in particular, cases of meta-scenographies. A reflection is raised on the uses of this motif, especially its use as a meta-artistic resource, its variants, as well as its temporality. From there, some examples of $2 \mathrm{O}^{\text {th }}$ century artistic avant-gardes where this iconography reappears are analyzed, either confirming the survival of the Euclidean vision or acquiring the meaning of painted meta-scenographies.

\section{Keywords}

Perspective; scenography; meta-scenography; meta-painting.

1. Universidad de Málaga. C. e.: romancg@uma.es

Este artículo es resultado del proyecto I+D HAR 2015-70089-P del Ministerio de Economía y Competitividad, titulado: Apropiaciones e hibridaciones entre artes plásticas y escénicas en la Edad Moderna. 
La escena urbana en perspectiva ilusionista característica del teatro y la pintura del Renacimiento italiano perdura a lo largo de los siglos y la hallamos de modo más o menos explícito en las artes visuales contemporáneas. Didi-Huberman, interpretando el afortunado término empleado por Aby Warburg, considera que la «supervivencia» de la imagen nos permite interrogar a la memoria actuante en las imágenes de la cultura. ${ }^{2}$ En este sentido, el presente artículo se dirige hacia un análisis sustentado en la cultura visual, por tanto, su objetivo no es dilucidar los términos de adecuación de la construcción perspectiva en la pintura, ni la organización geométrica o las posibles correspondencias o divergencias ópticas. Se trata, en cambio, de estudiar el uso de un prototipo escenográfico que constituye una imagen arquetípica en la tradición cultural europea. Desde este enfoque se pretende, particularmente, constatar su utilización como recurso metapictórico en la pintura desde los siglos de la Edad Moderna hasta encontrarlo, de modo más o menos ortodoxo u explícito, en obras contemporáneas. Siendo conscientes de la realidad visual de la cultura urbana en la que nuestra sociedad se halla inmersa en las últimas centurias se puede advertir, no obstante, la presencia de determinados elementos que constatan la fidelidad a un modelo a través de la supervivencia de una imagen arquetípica.

En consonancia con este planteamiento, sirva como punto de partida una obra como Las bellas errantes de Éfeso de Paul Delvaux, ${ }^{3}$ para repensar esa memoria de las imágenes. La evocación de la scena tragica diseñada por Sebastiano Serlio en Il Secondo Libro (I545) (Figura I) es evidente en la escenografía trazada por Delvaux: los edificios a ambos lados de una calle principal, un arco en el fondo de la composición, los voladizos de puertas y ventanas, así como las líneas del pavimento que apuntan hacia el fondo. Sin embargo, una contemplación más detenida nos permite advertir que, súbitamente, las líneas que conforman el ajedrezado del suelo hacen un quiebro y cambian ligeramente de dirección, distorsionando la perspectiva. ¿Trataba Delvaux de eludir con este gesto la ortodoxia renacentista que hacía coincidir los edificios fingidos a ambos lados del escenario con el telón pintado en perspectiva en el fondo? Es posible que de manera más o menos consciente intentara evitar la convención empleada en algunas pinturas del Renacimiento donde se advertía, tras la escena principal, la ficción de un telón de fondo, una suerte de metaescenografía.

El contenido metapitórico de la pintura europea a partir de la Edad Moderna ha suscitado el interés de prestigiosos investigadores empeñados en interpretar diversos recursos y artificios empleados por los pintores vinculados la tradición europea occidental. Baste recordar algunos hitos historiográficos, como el célebre análisis en torno al «cuadro dentro del cuadro» que incluyó Julián Gállego en su influyente libro Visión y símbolos en la pintura española del Siglo de Oro (I972), resultado de la tesis doctoral que defendió en la Sorbona bajo la dirección de Pierre Francastel. Dos décadas más tarde, Victor Stoichita publicó $L$ 'instauration du tableau. Métapeinture

2. Didi-Huberman, Georges: La imagen superviviente. Historia del arte y tiempo de los fantasmas según Aby Warburg. Madrid, Abada, 2009.

3. Paul Delvaux, Les belles Errantes à Éphèse (1946). Véase la imagen reproducida en el dossier de prensa (febrero, 2015) de la exposición organizada por el Museo Thyssen: Paul Delvaux: Paseo por el amor y la muerte <https://studylib. es/doc/6299331/paul-delvaux---museo-thyssen> [Consulta: 3-12-2019]. 


\section{M. SEBASTIAN SERLIO}

perfonaggi, clse rapprefentano il vino, come faria una femina ad un balcone, ò dentro d'pna porta, etiandio qualche animale: quefte cofe non configlio che fi faccino, perche non banno il moto of pure rapprefentano il uino: ma qualche perfona che dorma à buon propofito, ouero qualche cane, ò altro animale che dorma, perche non banno il moto. Ancora fi poffono accommodare qualche ftatue, ò altre cofe finte di marmo, ò d'altra materia, ò alcuna biftoria, ò fauola dipinta fopra un muro, che io loderò fempre fi faccia cosi. Ma nel rapprefentare cofe uiue, lequali babbino il moto : nell'eftremo di quefto libro ne tratterò, \& darò il modo come s'babbino à fare.

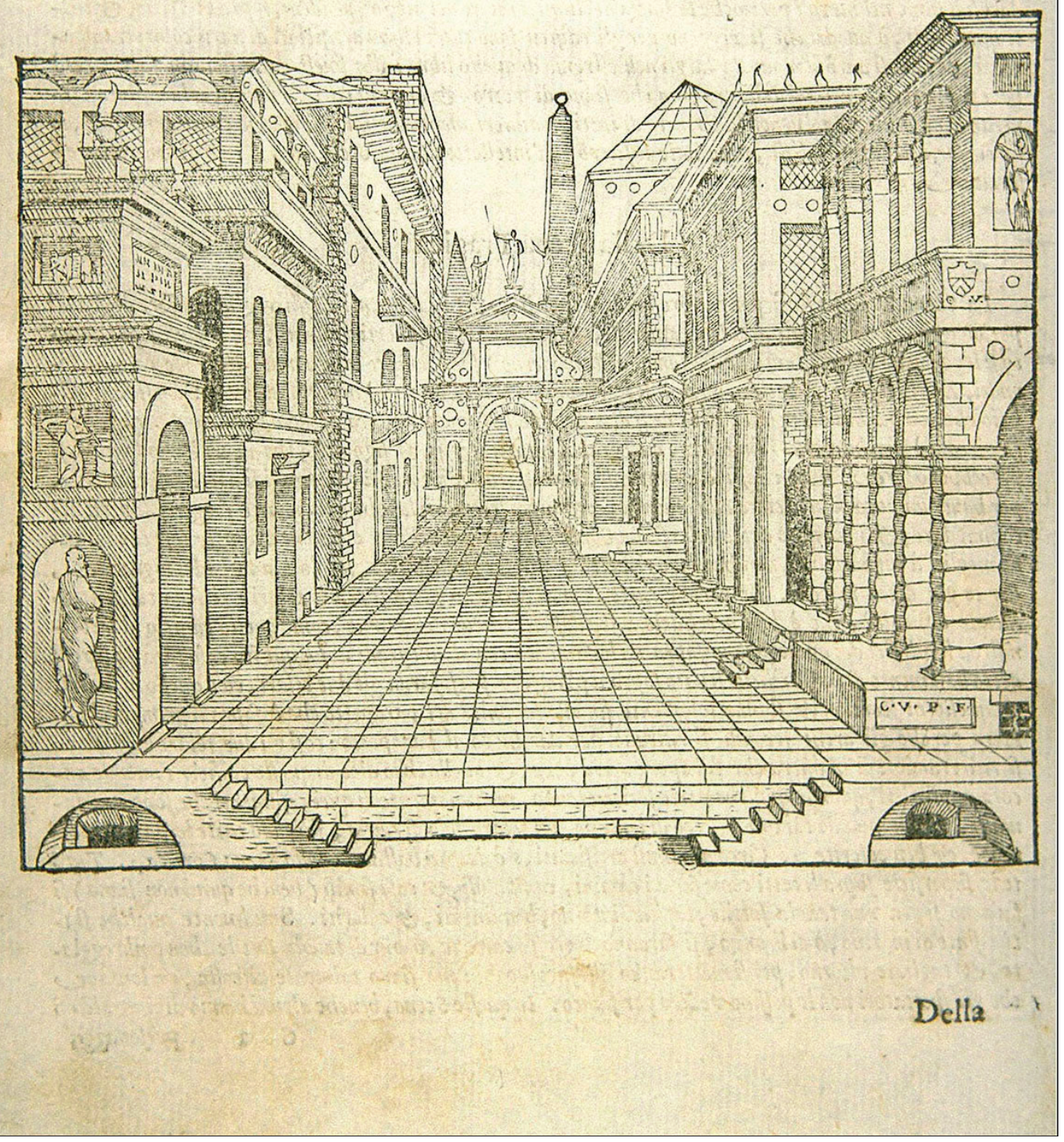

FIGURA 1. SCENA TRAGICA, EN IL SECONDO LIBRO DI PROSPETTIVA, DI SEBASTIANO SERLIO, BOLOGNESE, PARÍS, 1545. 
à $l^{\prime}$ aube des temps modernes (I993), ${ }_{4}$ donde amplió de manera exponencial y con una exquisita hermenéutica la función y significado de los motivos metapictóricos pintados en los cuadros. Más recientemente, la exposición comisariada por Javier Portús en el Museo Nacional del Prado y el catálogo que acompañó la muestra Metapintura. Un viaje a la idea del arte en España (2016), volvió a transitar por la intertextualidad y el mundo de las imágenes en la pintura dentro del contexto del Siglo de Oro español. Precisamente Portús, experto en las relaciones entre teatro y pintura en el Barroco, advierte que el contenido metapictórico de Las Hilanderas viene subrayado por el tapiz del fondo y añade: «hay que tener en cuenta lo habituado que estaba el público cortesano de la época a enfrentarse con obras similares, aunque no en forma de cuadros, sino a través de las obras teatrales, que planteaban problemas de interpretación y requerían métodos de lectura parecidos». Esta acertada afirmación permite enfocar oportunamente el análisis que pretendo desarrollar aquí, si bien, me voy a ocupar de un tema que hasta la fecha considero ha sido menos tenido en cuenta entre el «repertorio» de recursos metapictóricos. Me refiero al uso de un telón de foro pintado en perspectiva ilusionista detrás de la escena principal de un cuadro, la cual suele estar enmarcada, a su vez, por una escenografía arquitectónica. A ello me voy a referir al utilizar el término metaescenografía.

\section{LA ESCENOGRAFÍA EN LA PINTURA, LA PINTURA EN LA ESCENOGRAFÍA}

Desde el punto de vista general de la teoría de las artes, el término scenographia además de designar una de las disposiciones del dibujo de proyecto arquitectónico establecidas por Vitruvio (De Architectura, I,2), fue también utilizado por el mismo arquitecto romano en el prefacio a su Libro VIl cuando nos hace saber que Agatarco de Samos, a petición de Esquilo, realizó decorados para el teatro que representaban edificios, denominando a este tipo de representación scaenographia. Se trataba, según la descripción, de cuadros pintados sobre los paneles del escenario que, ajustándose a las leyes de la visión, ofrecían el aspecto de edificios verdaderos. ${ }^{5}$

El teatro, que ya en su nombre lleva implícito el acto de mirar (theâsthai), ocupó un lugar central en la cultura visual de la Edad Moderna, ${ }^{6} y$ lo hizo especialmente a partir del llamado escenario en perspectiva. Nos han llegado testimonios gráficos

4. La primera edición española publicada por Ediciones del Serbal (2000) lleva por título: La invención del cuadro. Arte, artífices y artificios en los orígenes de la pintura europea.

5. Sobre el desarrollo teórico de la perspectiva, así como su aplicación práctica, véase el indispensable ensayo de CAmerota, Filippo: La prospettiva del Rinascimento. Arte, architettura, scienza. Milán, Mondadori Electa, 2006. Sobre la relación entre la teoría de la perspectiva y las artes visuales y escénicas, véase GonZÁLEZ-RomÁN, Carmen: Spectacula. Teoría, Arte y Escena en la Europa del Renacimiento. Málaga, Universidad de Málaga, 2001.

6. BELTING, Hans: Florencia y Bagdad. Una historia de la mirada entre Oriente y Occidente. Madrid, Akal, 2012, p. 153 y ss. Véase también, GonZÁLEZ-RomÁN, Carmen: «Escenografías a la italiana en la corte de Felipe II», Goya, 331, 2010, pp. 99-109. 


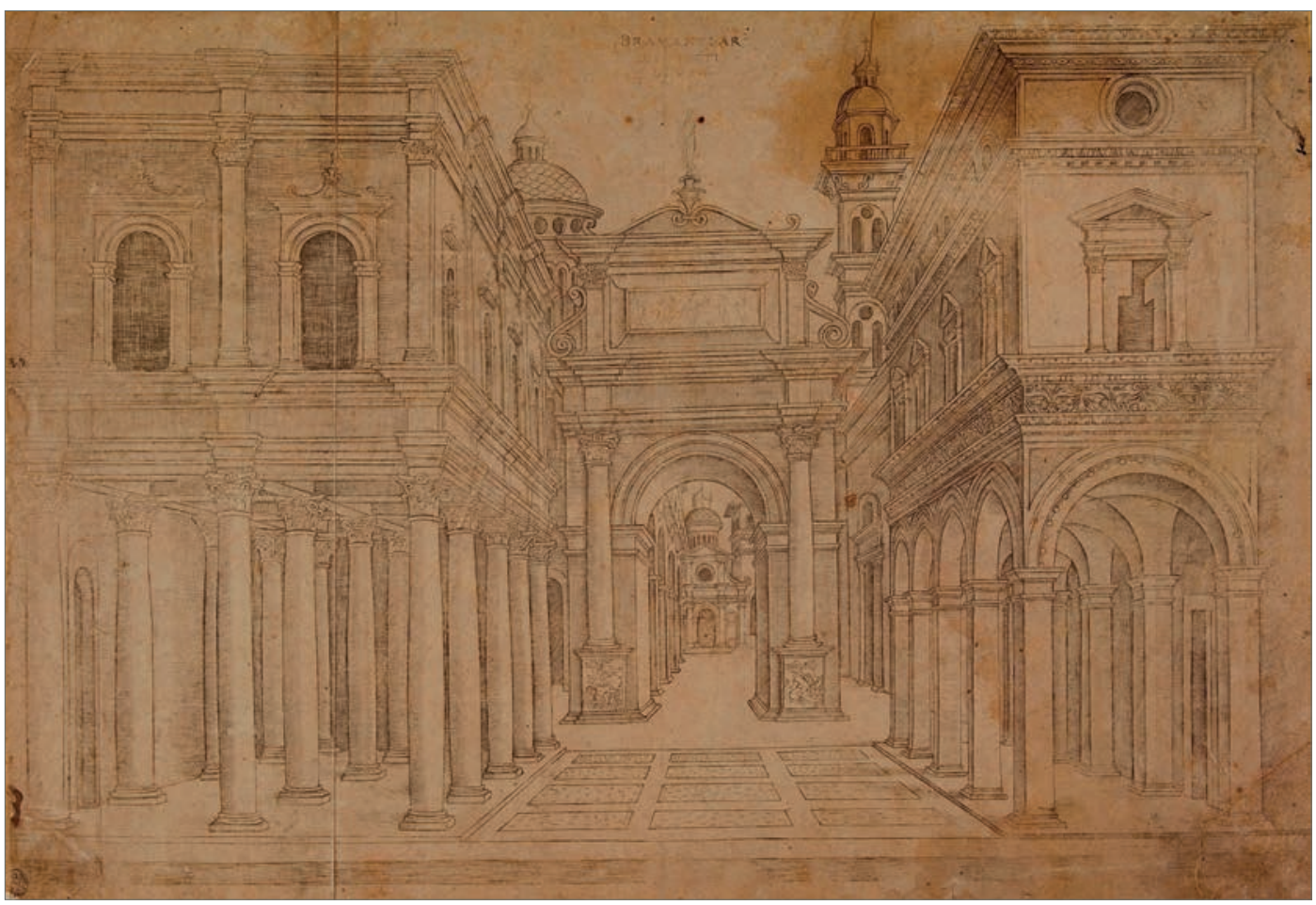

FIGURA 2. DONATO BRAMANTE (ATRIBUIDO), ESCENA EN PERSPECTIVA, FINALES XV - PRIMER CUARTO XVI. MILÁN, CASTELLO SFORZESCO, (C) CIVICA RACCOLTA DELLE STAMPE ACHILLE BERTANELLI.

que confirman el empleo de vistas urbanas en perspectiva desde fechas muy tempranas, como se aprecia en el singular grabado de finales del siglo $\mathrm{XV}$, atribuido a Bramante, en el que están presente motivos arquitectónicos que quedarán fijados unas décadas más tarde como prototipos para la escena (Figura 2). Del mismo modo, en una tabla atribuida Girolamo da Cotignola (Girolamo Marchesi), pintada en torno a 1520 (Figura 3), se estaba experimentando con recursos que se harán habituales en los escenarios: ajedrezado del pavimento, edificio cerrando la perspectiva urbana donde confluyen las líneas de fuga, etc., el mismo esquema que venía siendo utilizado también en taraceas. Merece la pena detenerse, brevemente, en este cuadro para advertir lo que ya podríamos considerar un «efecto telón» o una temprana metaescenografía pintada. Dicho efecto viene provocado por el modo en que el pavimento ajedrezado se interrumpe bruscamente allí donde terminan las fachadas de sendos edificios laterales y se «pinta» otra perspectiva de la ciudad. Las líneas de fuga van a parar a un singular edificio que contrasta -por los elementos de madera añadidos a la estructura original y la ropa suspendida sobre ellos- con la sobriedad clásica de la arquitectura de la escena principal. Pareciera como si los motivos que, según Vitruvio, constituían la scena tragica y la scena comica se fundieran en esta pintura años antes de que Serlio las sistematizara e individualizara en su Libro Segundo. De hecho, por el tema representado y la peculiar disposición de la doble escalinata que da acceso al escenario, este cuadro llegó a ser atribuido a Serlio. 


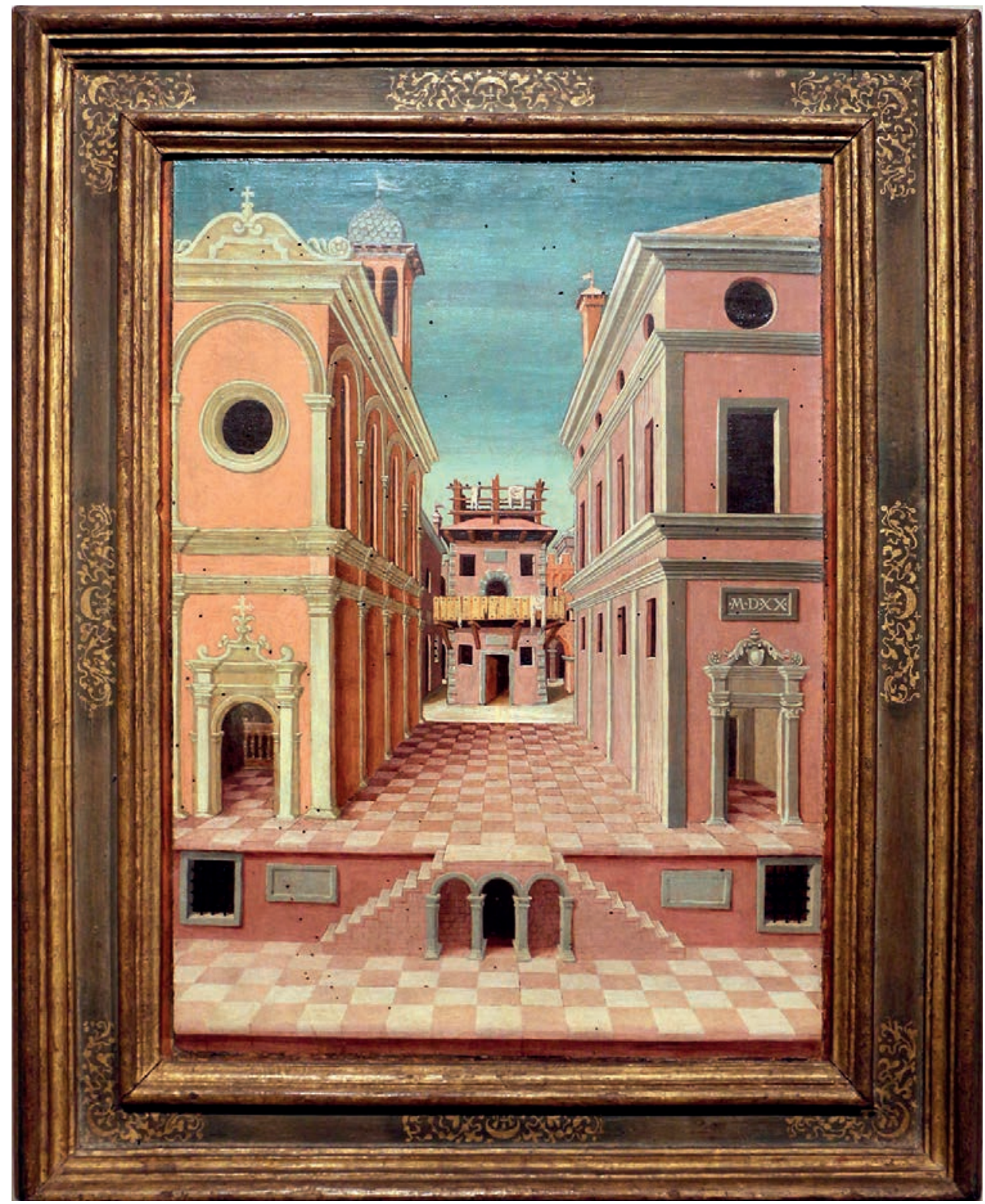

FIGURA 3. GIROLAMO DA COTIGNOLA (GIROLAMO MARCHESI) ATRIBUIDO. VEDUTTA DI CITTÀ (1520). PINACOTECA NAZIONALE (FERRARA). FUENTE: WIKIMEDIA COMMONS. DOMINIO PÚBLICO.

Este tipo de imágenes conteniendo vistas urbanas coinciden con las descripciones de comedias que nos han llegado. ${ }^{7}$ La mención más antigua que se conoce de un decorado ilusionista pintado y/o construido en perspectiva se refiere a la primera representación de la Cassaria de Ariosto, que tuvo lugar en Ferrara en I508, cuyo

7. Véase al respecto el imprescindible ensayo de E. Battisti: «La interpretación de la escena clásica en la comedia humanística», en BATTISTI, Eugenio: Renacimiento y Barroco. Madrid, Cátedra, 1990, pp. 73-83. También el capítulo de DAMISCH, Hubert: «Figuras de la desenvoltura» en, DAMISCH, Hubert: El origen de la perspectiva. Madrid, Alianza, 1997, pp. 167-196. 
decorado pintado por Pellegrino di San Daniele, consistía en una perspectiva que agrupaba diversos edificios, casas, iglesias y campanarios, rodeados de jardines, y era tan placentera a la vista que, según se nos dice, habría merecido ser conservada para poderse utilizar en otras ocasiones. ${ }^{8}$ Semejante disposición se deduce, según Hubert Damish, del texto de Vasari que trata del escenario y de las «perspectivas» concebidas por Franciabigio y Ridolfo Ghirlandaio para las comedias representadas en Florencia con ocasión de las nupcias de Lorenzo de Medicis, así como de la descripción que ofrece Baldassare Castiglione del escenario para la comedia Calandria de Bibiena representada en Urbino en I513, en una puesta en escena de Girolamo Genga. Otro notable humanista, Maquiavelo, indicaba en su comedia La Mandragola (I5I8):

\begin{abstract}
«Ved la decoración que os presentamos; Esta es vuestra Florencia, (Pisa o Roma será mañana/El argumento es para morirse de risa/. La puerta que está a mano derecha, esa es la casa de un doctor/quien aprendió en su Boecio muchas leyes./ Ese camino que está dispuesto en el fondo/ Es el camino del amor,/ donde el que cae nunca sale [...]/ [sigue el relato refiriéndose a otros elementos, por ejemplo, «el Templo que se ve en el frente» $[\ldots] .^{9}$
\end{abstract}

En este escenario los actores debían situarse en la parte delantera del mismo evitando desplazarse hacia el fondo pues, si eso sucedía, se alteraba el efecto logrado por el decorado ya que las casas simuladas a ambos lados del escenario disminuían su altura hacia el fondo hasta coincidir con la perspectiva pintada en el telón de foro. La disposición sería semejante a la que muestra un grabado contenido en la edición de la comedia Il Pellegrino, publicada en Venecia en I552. Así configurado el escenario, el teatro invitaba a una doble mirada: delante, al lugar de la representación, $\mathrm{y}$ al fondo, al lugar de la perspectiva. ${ }^{\mathrm{IO}}$

Las descripciones sobre las comedias representadas se han relacionado en numerosas ocasiones con las tres famosas tablas que representan la ciudad ideal, y sobre cuyo autor no hay consenso. Me refiero a las conocidas como tablas de Urbino, Baltimore y Berlín, que han sido interpretadas como proyectos para escenografías, composiciones-tipo, o representaciones utópicas de ciudades ficticias. A este respecto, $\mathrm{H}$. Damisch lejos de considerarlas proyectos de escenografías, señala que estas obras «resultan dependientes de un grupo de transformaciones que se incluye, a su vez, en una serie mucho más larga, y que no es necesariamente homogénea, ni

8. Carta de Bernardino Prosperi a Isabel d'Este, citada por DAMISCH, Hubert: op. cit., p. 181.

9. Machiavelli, 1518, cfr. González-Román, Carmen \& Solís, Isabel: «Reconstructing the image of the ideal city in Renaissance painting and theatre: Its influence in specific urban environments. Digital technology and visual culture», en GAGO, Alexandra \& alii. (eds.): Cities in the Digital Age: Exploring Past, Present and Future. Lisboa, CITCEM, 2019, pp. 29-45. Antonio Bonet Correa, en su nombramiento como Doctor Honoris Causa por la Universidad de Málaga (2014) pronunció un discurso en el que llevó a cabo un exquisito y enriquecedor punto de vista sobre la relación entre la perspectiva, la escenografía y el poder en la obra del célebre humanista. Véase BONET CORREA, Antonio: «La perspectiva, el territorio y la escenografía renacentista en Maquiavelo», Boletín de Arte, 25 (2014), pp. 27-41.

10. Belting, Hans: op. cit., p. 154. Tal y como sostiene H. Belting, en el siglo XVII la situación del escenario renacentista cambiará, pues se podrá actuar en el fondo del escenario, con lo cual se perdió el carácter de imagen separada y la impresión de campo visual homogéneo desapareció para permitir la ilusión de los espacios cambiantes, de este modo, los constructores de máquinas llegaron a ser más importantes que los pintores. Idem, p. 161. 
en cuanto al «género» ni en cuanto a la «sustancia». ${ }^{\text {II }}$ Este punto de vista, justo es decirlo, nos ofrece la oportunidad de resituar el análisis del modelo escenográfico que aquí tratamos en un ámbito de estudio más amplio e integrador como es el de la cultura visual.

Con todo, en el año I545, el arquitecto boloñés Sebastiano Serlio, que había vivido en Venecia y compartido amistad con los artistas más notables del momento, Tiziano o Sansovino, entre otros, publicó su Libro Segundo, dedicado a la perspectiva, el cual contenía el primer Tratado sobre la escena. En dicho tratado Serlio incluye tres grabados donde sistematizó los decorados teatrales para la tragedia, la comedia y la sátira, descritos por el arquitecto romano Vitruvio en el siglo I a.C. La scena tragica representa un paisaje urbano noble, con palacios, templos y monumentos antiguos, sin duda un modelo de ciudad ideal acorde con la imagen que venía siendo recreada de la ciudad en la Antigüedad clásica, tanto en la pintura como en los escenarios.

La imagen de la ciudad en perspectiva, presente en tempranas pinturas del Quattrocento, se convirtió en un prototipo que tras la sistematización serliana hallamos total o parcialmente, de modo explícito o sugerido, en fondos de pinturas a lo largo del siglo XVI. ${ }^{\mathrm{I2}}$ Entre los muchos ejemplos que podríamos señalar, se encuentra el fresco pintado por Pomarancio en la Sala de las hazañas de Ascanio, El duelo de Pitigliano (1574-I590), en el Palazzo della Corgna.

En consecuencia, la nueva concepción en perspectiva de las vistas urbanas invitaba a la mirada del espectador a adentrarse en el interior. Así lo llegó a advertir el mismísimo Velázquez cuando, a propósito del Lavatorio de Tintoretto, del que me ocuparé a continuación, exaltó:

[...] la «disposición de su perspectiva, que juzga poderse entrar por él, y caminar por su pavimento enlosado... $\gg^{13}$

\section{ESCENOGRAFÍAS Y METAESCENOGRAFİAS PINTADAS. DE TINTORETTO A PICASSO}

Uno de los grandes maestros de la escuela veneciana, Tintoretto, que a lo largo de su vida se ocupó del diseño del vestuario y la escenografía para la representación

\footnotetext{
11. Damisch, Hubert: op. cit., p. 332.

12. Entre la amplia bibliografía al respecto, cabe mencionar: Zorzı, Ludovico: // teatro e la città. Torino, Einaudi, 1977; RuffinI, Franco: Commedia e festa nel rinascimento. La Alandria alla corte di Urbino. Bologna, II Mulino, 1986; TAMBURINI, Elena: /l quadro della visione. Arcoscenico e altri sguardi ai primordi del teatro moderno. Roma, Bulzoni, 2004; Aliverti, M. Inés: Una scena di città attribuita a Sebastiano Serlio: breve saggio di iconología teatrale. Pisa, ETS, 2008. Véanse también las aproximaciones a esta temática realizadas por MERINO PERAL, Esther, entre otras aportaciones: El reino de la ilusión: Breve historia y tipos de espectáculo, el arte efímero y los orígenes de la escenografía. Universidad de Alcalá, 2006.

13. De los Santos, Fray Francisco: Memoria de las pinturas (1658), cfr. Molina Foix, Vicente: Tintoretto y los escritores. Madrid, Galaxia Gutemberg, Museo Nacional del Prado, p. 255. Véase también Falomir, Miguel: Tintoretto. Museo Nacional del Prado, El Viso, 2007, p. 174. Según Falomir, en la descripción que del Lavatorio recoge la llamada «Memoria de Velázquez», «aparecen enunciadas, por primera vez, nociones que habrían de tornarse habituales durante siglos al analizar Las Meninas, como la famosa perspectiva aérea».
} 
de diversas comedias en Venecia, se inspiró en la scena tragica serliana para componer los fondos pintados de algunas de sus más célebres obras. Su biógrafo, Carlo Ridolfi, dice de Tintoretto:

«inventó originales e ingeniosos trajes para la representación de las comedias que se recitaban en Venecia... inventando muchas curiosidades que maravillaron a los espectadores, y eran celebradas por extraordinarias, de manera que todos acudían a él en semejantes ocasiones». ${ }^{14}$

Hemos de suponer que entre las curiosidades que maravillaron a los espectadores se encontrarían sus diseños de perspectivas para la puesta en escena de las comedias, destreza que también demostró sobradamente en sus pinturas. Convendría también tener presente, a este respecto, que Tintoretto mantuvo una estrecha relación con el grupo de los denominados Polígrafos, grupo que en Venecia estaba integrado por poetas, editores y hombres de teatro, y que uno de sus mejores amigos fue Andrea Calmo, un comediógrafo veneciano. ${ }^{15}$ También sabemos, siempre siguiendo las noticias que aporta su biógrafo, que Tintoretto intervino en la decoración de grandes escenografías construidas en la ciudad de Venecia, como fue el arco efímero levantado en el Lido para el desembarco de Enrique III, rey de Francia (coronado rey en 1575). En esta empresa el artista colaboró con Paolo Veronese, ambos bajo la dirección del insigne arquitecto Andrea Palladio, quien ya había realizado en Vicenza un teatro en madera a la manera clásica. ${ }^{16}$ Más tarde, el mismo arquitecto levantó en Venecia, en torno a $1564-65$, otro teatro desmontable, posiblemente en el claustro del monasterio de la Caridad, cuyo escenario dispondría de un frons scaenae con un triple pasaje tras el que se podrían contemplar escenas de calles en perspectiva. ${ }^{17}$ De los teatros en madera construidos por Palladio solo han llegado descripciones, si bien toda aquella experimentación quedaría definitivamente materializada años después en el extraordinario Teatro Olímpico vicentino.

El contacto de los pintores venecianos con Andrea Palladio fue determinante en la concepción escenográfica de algunas de las más conocidas pinturas de esta escuela. En Cristo en casa de Leví (I573), Veronés sitúa a los personajes en un extraordinario pórtico concebido a la manera de un frons scaenae y detrás pinta un telón figurando una ciudad. Este telón de foro constituye un singular ejemplo de metaescenografía, esto es, una escenografía situada tras la escenografía que envuelve la escena principal del cuadro. En este contexto veneciano se venía empleando desde hacía varias

\footnotetext{
14. Ridolfi, Carlo: Vita de Giacopo Robusti detto il Tintoretto... Venecia, Guglielmo Oddoni, 1642, p. 88.

15. Molina Folx, Vicente: op. cit, pp. 25-26.

16. Palladio, junto con Giangiorgio Trissino se había estrenado en el terreno de lo efímero en una «bianca scenografia di architetture affimere all' antica: archi trionfali, frontonio, pitture a chiaroscuro addossati agli edifici, lunto un percorso ritmato da obelischi e stature colossali», para la entrada en Vicenza en 1543 del cardenal Noccolò Ridolfi, cfr. Beltramini, Guido: «Andrea Palladio 1508-1580», en Beltramini, Guido \& Burns, Howard (eds.): Palladio. Venezia, Marsilio Editore, 2008, p. 2.

17. González-Román, Carmen: Spectacula..., pp. 193-210.
} 


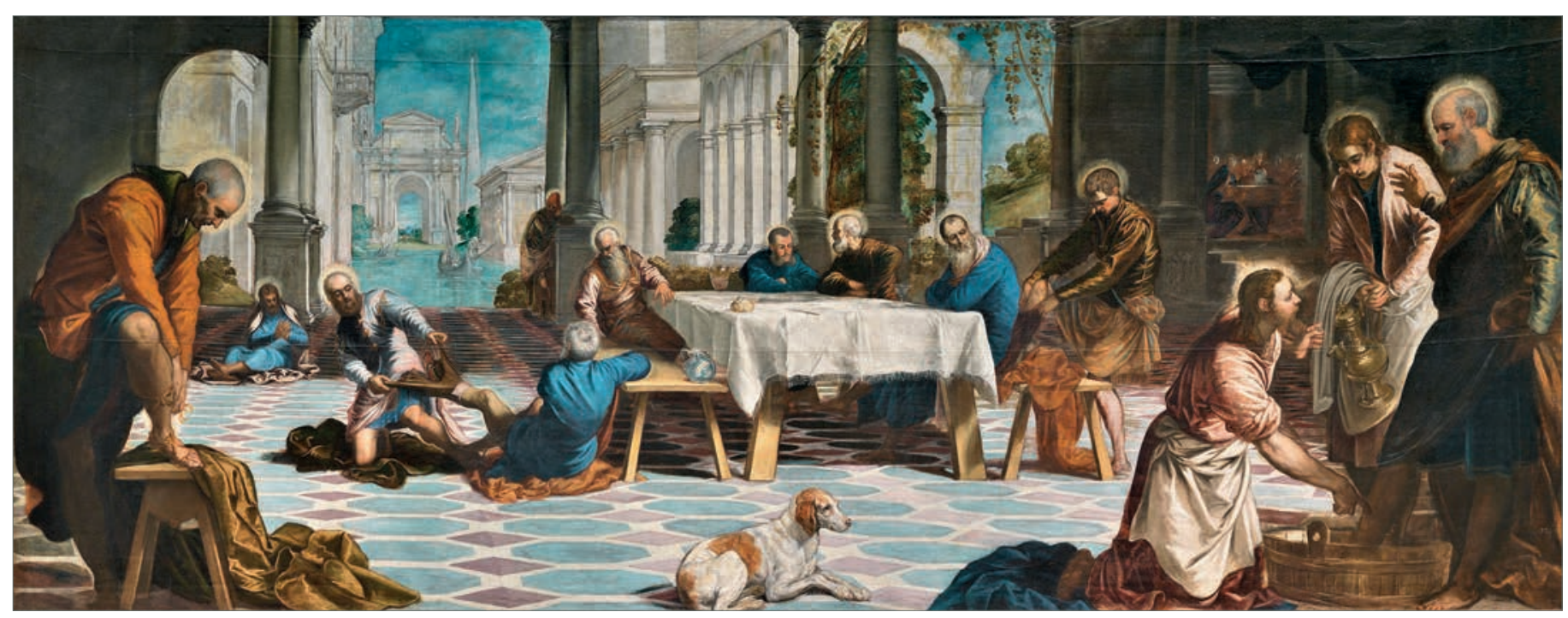

FIGURA 4. JACOPO TINTORETTO. EL LAVATORIO, 1548 - 1549. MADRID, MUSEO NACIONAL DEL PRADO.

décadas este recurso y es donde debemos situar una de las obras maestras de Jacopo Tintoretto: El Lavatorio (ha. 1547) (Figura 4). ${ }^{18}$

Carlo Ridolfi cuenta, en otro conocido pasaje de la vida de Tintoretto, que para pintar utilizaba «curiosos artificios» que consistían en pequeños modelos de cera y de arcilla vestidos con trapos para estudiar mejor los pliegues de los paños y las partes desnudas. Estas figuras las colocaba dentro de, dice literalmente Ridolfi, «pequeñas casas y perspectivas, compuestas con tablas de madera y cartones». La descripción no puede ser más elocuente y debemos interpretar estos artificios como pequeños teatrillos que en sí mismos resultaron, según Ridolfi, «extraordinarias invenciones». ${ }^{19}$ En uno de estos pequeños teatros iluminados con velas es posible que Tintoretto concibiera esta gran tela, colocando figurillas que representarían a personajes populares con un aspecto similar a los que aparecían en las comedias de su ya mencionado amigo Andrea Calmo, y con los que el público se identificaba fácilmente, al tiempo que por su aspecto humilde, coincidían con el ideario de las reglas de la cofradía del Santísimo Sacramento de la iglesia de San Marcuola en Venecia, para cuya iglesia fue originalmente realizada la obra.

En el libro publicado por el Museo Nacional del Prado el año 2000 con motivo de la restauración de El lavatorio, Miguel Falomir incluía una reconstrucción virtual del escenario de esta obra desprovisto de los «actores». Con ello quería advertir que la teatralidad que destila este impresionante lienzo probablemente se deba más a aquella forma de trabajar de Tintoretto, es decir, construyendo primero un escenario con ayuda de una rigurosa perspectiva e insertando después los personajes en él. ${ }^{20}$

18. En 1547 la Scuola del Santísimo Sacramento de la iglesia de San Marcuola en Venecia encargó a Jacopo Tintoretto el Lavatorio y una Última Cena, aún in situ.

19. Ridolfi, Carlo: op. cit., p. 8.

20. FAlomir, Miguel: Una obra maestra restaurada. El Lavatorio de Jacopo Tintoretto. Madrid, Museo Nacional del Prado, 2000. 
Desde mi punto de vista, además, la composición constituye un singular ejemplo de metaescenografía. El escenario de El lavatorio es un monumental pórtico abierto a un imaginario canal veneciano que aparece como telón de foro. Tintoretto supo resolver con habilidad la transición entre el escenario en el que tiene lugar la acción y el decorado del fondo, tratando de evitar el «efecto telón», como advirtió David Rosand, mediante la introducción de unos arbustos estratégicamente situados allí donde el termina el pavimento. ${ }^{21}$ Resulta evidente la «cita serliana», como se percató a comienzos de los sesenta Cecil Gould, ${ }^{22}$ si bien los elementos de la scena tragica han sido simplificados por el pintor. Coinciden varios motivos, como las fachadas situadas a ambos lados, el balcón volado sobre un edificio de la izquierda, el templo coronado por frontón que, situado a la derecha, sobresale de la línea de la calle, el arco de triunfo que cierra la perspectiva, o el obelisco colocado a la derecha.

El mismo decorado serliano se advierte en otra obra pintada por Tintoretto unos seis años más tarde: Cristo y la adúltera (1555), conservado en el Rijksmuseum. Resulta curioso el modo en que Tintoretto resuelve en esta ocasión la transición entre el espacio escenográfico que ocupan los personajes y el telón de foro. El pintor sitúa tras el pavimento una estrecha franja ajardinada donde coloca algunas figuras, para

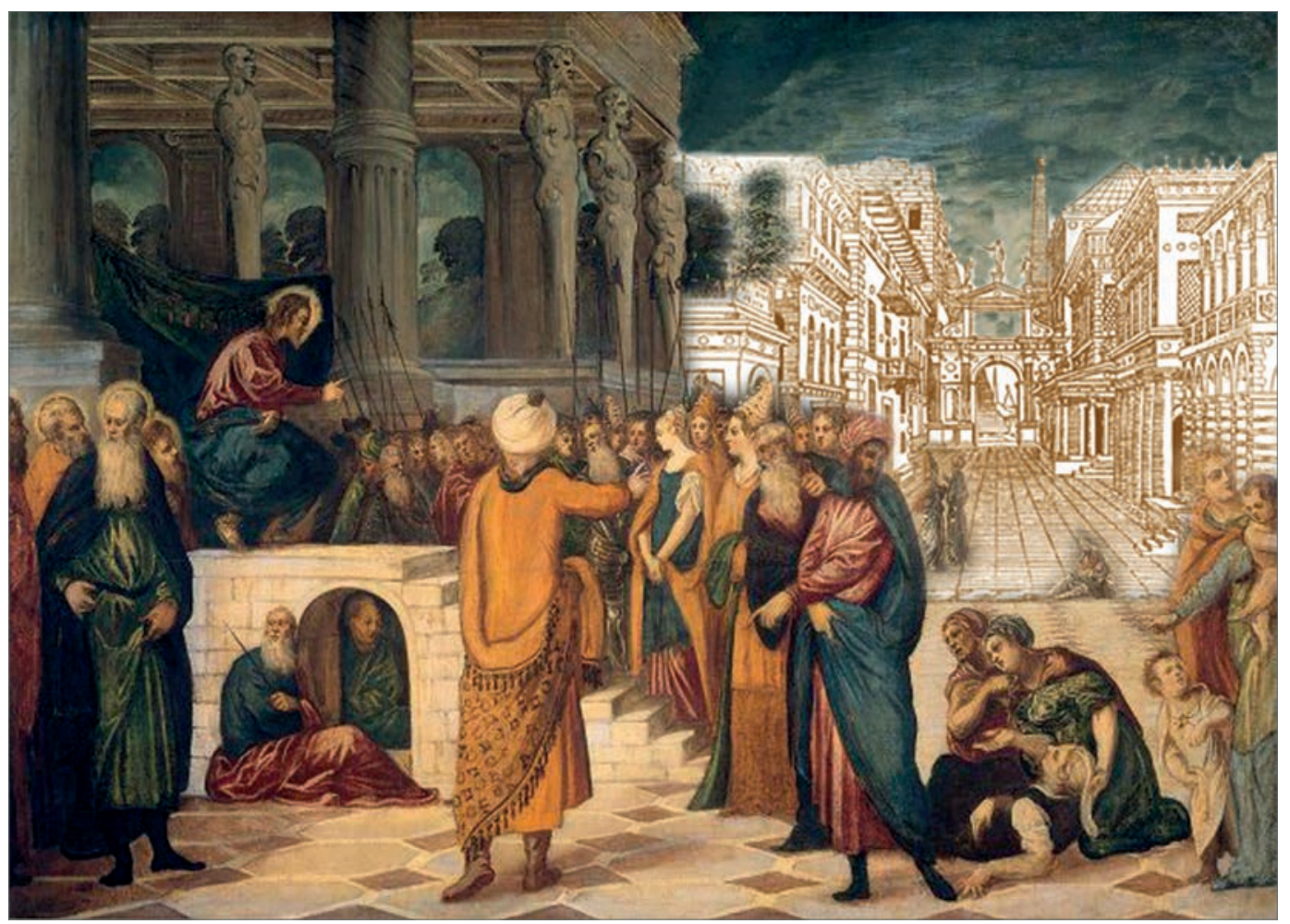

FIGURA 5. JACOPO TINTORETTO. CRISTO Y LA ADÚLTERA, 1550-1580. AMSTERDAM, RIJKSMUSEUM. IMAGEN TRATADA DIGITALMENTE POR ISABEL SOLÍS ALCUDIA.

21. Rosand, David: «Theater and Structure in the Art of Paolo Veronese», en Rosand, David: Painting in Cinquecento Venice. Titian, Veronese, Tintoretto. New Haven, Yale University Press, 1982.

22. Gould, Cecil: «Sebastiano Serlio and Venetian Painting». Journal of the Warburg and Courtauld Institutes, 25 (1962), citado por FALOMIR, Miguel: Una obra maestra restaurada, p. 57. 
pasar a continuación a dibujar la escena serliana en la que se advierte con claridad las líneas de fuga del pavimento (Figura 5$)^{23}$

Tintoretto demostró un asombroso rigor en el uso de la perspectiva, pero a medida que fue desarrollando su estilo se fue deshaciendo del esquema canónico inspirado en el escenario serliano. Esto es lo que apreciamos en La Última Cena de la iglesia de San Trovaso en Venecia, una pintura que también parece ser el resultado de aquellas composiciones que el pintor veneciano ideaba colocando figuritas de cera o de barro en un pequeño escenario. ${ }^{24}$ Ahora bien, resulta sumamente interesante el modo en que el decorado del fondo empleado aquí por el artista se asemeja más, dadas las dimensiones, a un tapiz que a un telón. Si nos acercamos al cuadro, advertimos que prácticamente no hay ningún elemento de transición entre la escena principal interior y el fondo más luminoso que se recorta con total definición tras ella, acentuando, en este caso, un «efecto tapiz». ${ }^{25}$

Como es sabido, El Greco sintió admiración por la pintura de Tintoretto, en especial por aquella de las profundas y estudiadas perspectivas urbanas. ${ }^{26}$ En el momento de su llegada a la ciudad de los canales en 1567 , el célebre pintor veneciano estaba en el mejor momento de su carrera inmerso en uno de los mayores proyectos de la segunda mitad del XVI, la decoración de la Scuola de San Rocco, sin embargo, la producción temprana de El Greco no delata el impacto de esas obras contemporáneas, sino de las realizadas por Tintoretto veinte años atrás. Posiblemente las pinturas de San Rocco eran demasiado complejas y no servían como modelo a un pintor primerizo como era El Greco entonces, que de manera autodidacta debía iniciarse en la «forma latina» de pintar, comenzando por adquirir las nociones básicas sobre perspectiva y anatomía necesarias para realizar una buena composición a la manera occidental. De este modo, «El Greco encontró su guía en las obras de Tintoretto que habían servido a éste para progresar en la década de $1540 »{ }^{27}$

Entre las formas y convenciones que asimila el pintor cretense del célebre artista veneciano, un papel importante lo desempeñan los fondos concebidos como escenografías a la manera serliana. En algunas de las versiones de La curación del ciego, pintadas por El Greco en Venecia o Roma antes de su traslado a España en I576, advertimos los motivos tintorettianos: suelos con despiece geométrico y

23. Sobre la cultura arquitectónica y el valor de la perspectiva en Tintoretto, veáse, entre otras publicaciones la reciente aportación de Grosso, Marsel y GuIdARELLI, Gianmario: Tintoretto e lárchitettura. Venezia, Marsilio, 2018.

24. FALOMIR, Miguel: Tintoretto..., p. 307.

25. No puedo dejar de volver a mencionar aquí el excelente estudio de Javier Portús en el catálogo de la exposición Metapintura. Un viaje a la idea del arte en España donde, a propósito del contenido metapictórico de Las Hilanderas subrayado por el tapiz del fondo.

26. Acerca de la relación de El Greco con la arquitectura y la perspectiva, véanse desde los clásicos estudios de Wethey, Harold Edwin: El Greco and his School. Princeton, Princeton University Press, 1962, o de Pavón Maldonado, Basilio: «El Greco arquitecto», Archivo Español de Arte, 35, 1962, pp. 209-220; pasando por imprescindibles investigaciones al respecto realizadas en torno a la figura de El Greco por MARíAs, Fernando, y de la cual baste mencionar aquí el libro publicado junto a Bustamante, Agustín: Las ideas artísticas de El Greco. Madrid, Cátedra, 1981. Más recientemente, BÉRCHEZ, Joaquín: El Greco. Architeto de retablos. Madrid, Instituto Cervantes, 2014; Véase, así mismo, GonzÁlez-Román, Carmen: «Más de 'opiniones y paradojas'. El Greco y las ideas en torno a la arquitectura en la España de su época», en AlmarCHA, Esther \& alii.: El Greco en su IV Centenario: patrimonio hispánico y diálogo intercultural. Toledo, Universidad de Castilla- La Mancha, 2016, pp. 425-444.

27. Falomir, Miguel: «El Greco y la pintura veneciana», Archivo secreto. Revista cultural de Toledo, 6 (2015), p. 257. 


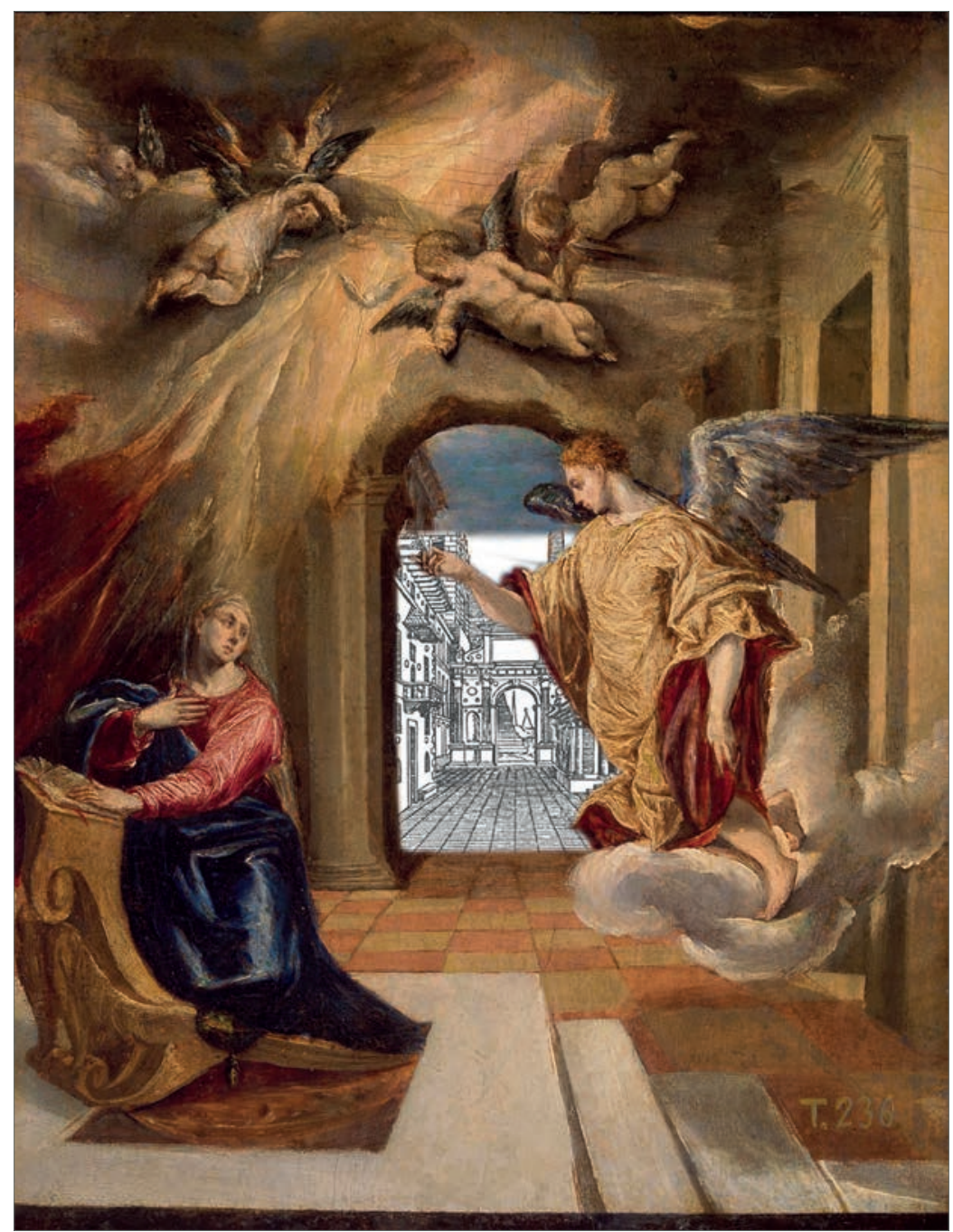

FIGURA 6. EL GRECO, LA ANUNCIACIÓN, 1570-1572. MADRID, MUSEO NACIONAL DEL PRADO. IMAGEN TRATADA DIGITALMENTE POR ISABEL SOLÍS ALCUDIA.

arquitecturas proyectadas hacia un punto de fuga. No hay que perder de vista que se trata de obras anacrónicas en el panorama pictórico italiano de los años 70. A su etapa italiana pertenece también La Anunciación (I570-1572) del Museo Nacional del Prado. El paisaje urbano que pinta El Greco en este cuadro reproduce el tipo de perspectiva empleada, como hemos visto, por Tintoretto, aunque la vista urbana se nos presenta aquí con menos de definición. Sin embargo, un tratamiento digital de dicho fondo permite hacer coincidir el arco que cierra la perspectiva, así como detalles concretos de la fachada de los edificios situados a la izquierda con los pórticos y con el balcón característico de la escenografía serliana (Figura 6). Esta vista urbana funciona aquí de nuevo como una metaescenografía, resultando particularmente interesante el modo en que el pintor parece querer hacer explícito el recurso de telón pintado. Si miramos con atención, allí donde se interrumpe el ajedrezado del pavimento del edificio que acoge la escena se advierten unos bordes blancos que acentúan un efecto telón. Con ello, parece querer deslindar el espacio de la representación del espacio 
figurado. ${ }^{28}$ El cretense siguió incluyendo vistas urbanas en sus pinturas, como se advierte en las distintas versiones de La expulsión de los mercaderes del templo pero, como le sucedió a su admirado maestro veneciano, al ir desarrollando su estilo aquellas imágenes se hicieron más lacónicas hasta prácticamente desaparecer.

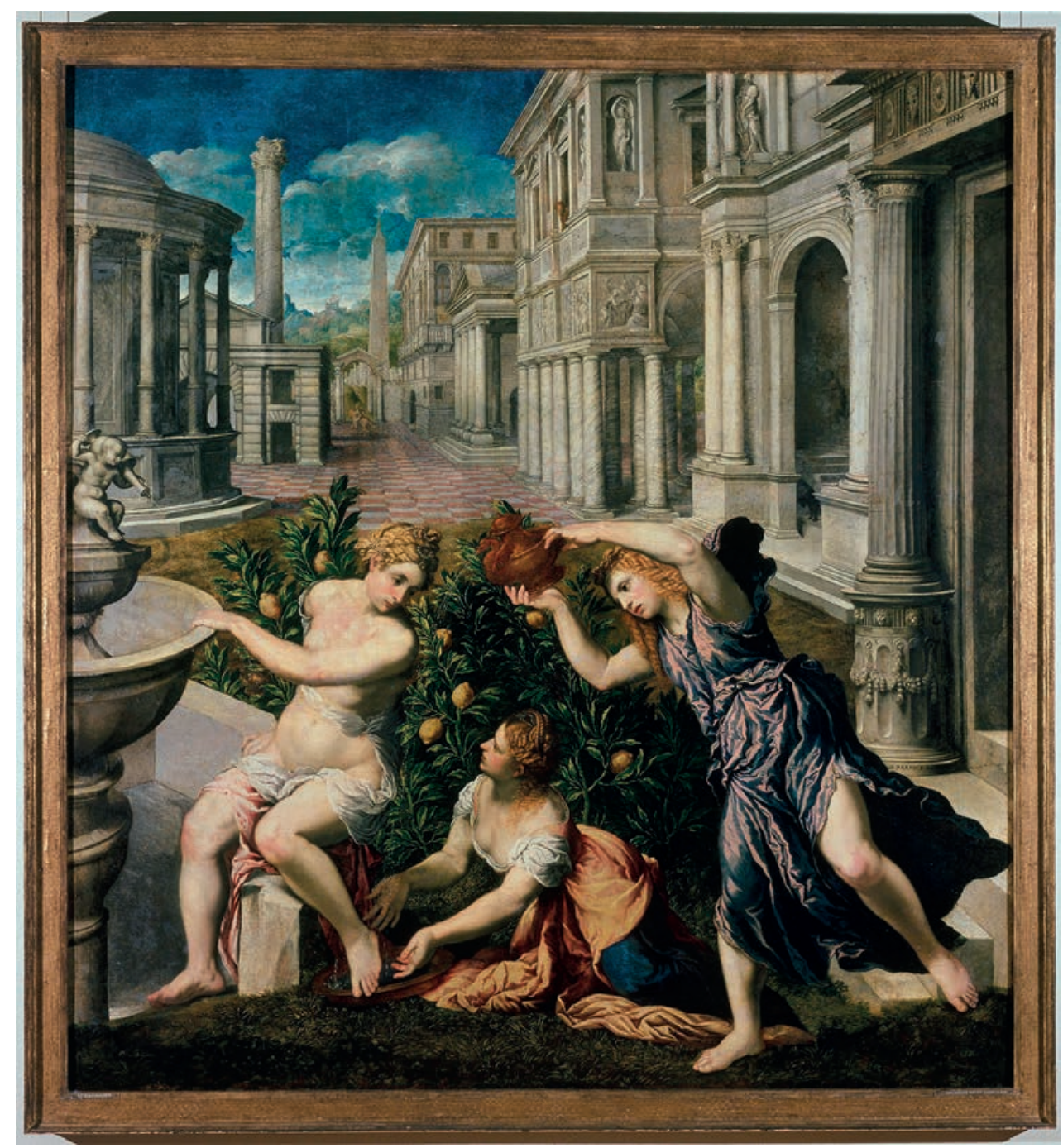

FIGURA 7. PARIS BORDONE, EL BAÑO DE BETSABÉ, H. 1545. COLONIA, WALLRAF-RICHARZT MUSEUM. PHOTO: (C) RHEINISCHES BILDARCHIV

En el entorno artístico veneciano encontramos otros ejemplos de metaescenografías pintadas. Paris Bordone, que fue reconocido como excelente pintor de perspectivas, ${ }^{29}$ en el cuadro titulado El baño de Betsabé (Figura 7), datado

28. Ineludiblemente, se hace preciso a este respecto volver a mencionar aquí el imprescindible libro de STOICHITA, Victor: La invención el cuadro. Arte, artífices y artificios en los orígenes de la pintura europea. Barcelona, Ediciones del Serbal, 2000.

29. BoschINI, Marco: Le ricche minere della pittura veneziana. Venezia, Francesco Nicolini, 1674. Boschini señala respecto a Paris Bordone «Nell'Architettura poi fece maraviglie: oiche si vedono esempi di sfuggimenti di 
en torno a I545-I549, sitúa detrás del jardín donde se encuentran los personajes principales, un pavimento sobre el que se asienta la scena tragica serliana. Al prestigioso historiador del arte Hans Belting no le pasó inadvertido de qué manera «en este cuadro la relación entre pintura y teatro se invierte, es decir, la perspectiva teatral transforma también la obra en un teatro pintado». ${ }^{30}$ En otras obras, Bordone siguió inspirándose en el escenario serliano, como en La aparición de la Sibila a Augusto (ha. I550) del Museo Puskin de Moscú, si bien en esta pintura, como en otras más tardías, lo que antes constituía la iconografía del telón de foro pasa a un primer plano de la composición, acogiendo a personajes que transitan por escenarios sobredimensionados. Así se advierte también en la Batalla de gladiadores del Kunsthistorischesmuseum de Viena (ca. 1560) (Figura 8), donde nuevamente un grandilocuente escenario urbano envuelve escenográficamente la concurrida escena donde tiene lugar la lucha.

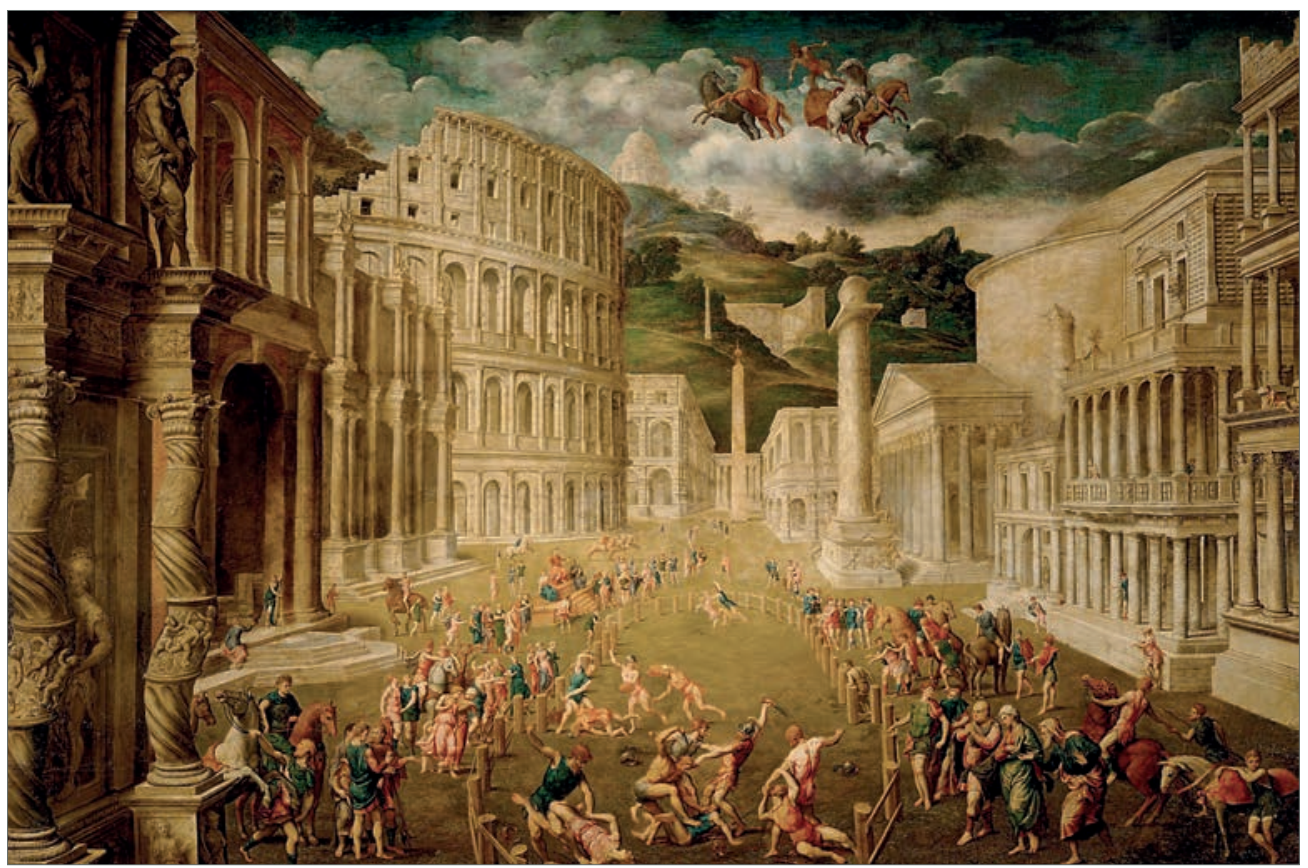

FIGURA 8. PARIS BORDONE, BATALLA DE GLADIADORES, CA. 1560. VIENA, KUNSTHISTORISCHES MUSEUM, GEMÄLDEGALERIE.

En el siglo XVIl fueron varios los pintores paisajistas que destacaron por sus vedute. Sin embargo, y pese a la prestancia otorgada por muchos de ellos a las profundas y calculadas perspectivas arquitectónicas, la imagen del decorado serliano se fue desvaneciendo. De un lado, surgieron visiones de la ciudad contemporánea en las que se realzan las nuevas construcciones y ámbitos urbanos, como la Basílica de San Pedro o las grandes plazas. En ocasiones, los artistas reflejan una imagen

Prospettiva cosi bene rappresentati che formano concerti di rarità, ed in particolare nell' Albergo della Scola di San Marco, ove esso auttore figurò l' Historia, quando quel Vecchio Barcauolo portò in Collegio al Serenissimo Prencipe I' anello datogle da San Marco, che veramente è cosa rara...», pp. 56-57.

30. Belting, Hans: op. cit., pp. 160-164. 
idealizada y nostálgica de las ruinas, como advertimos en las vistas del foro (Campo Vaccino) de Claudio de Lorena. Y aunque edificios como el Coliseo o los templos clásicos no dejan de estar presente en las composiciones alegóricas de Lorena, como en Paisaje con el entierro de Santa Serapia (ca.I639, Museo Nacional del Prado), tales monumentos aparecen subsumidos en un entorno bucólico o pintoresco. Con todo, aún hallamos la influencia de la scena tragica serliana en La Peste de Asdod, pintada por Nicolas Poussin (I630-I63I) (Figura 9).

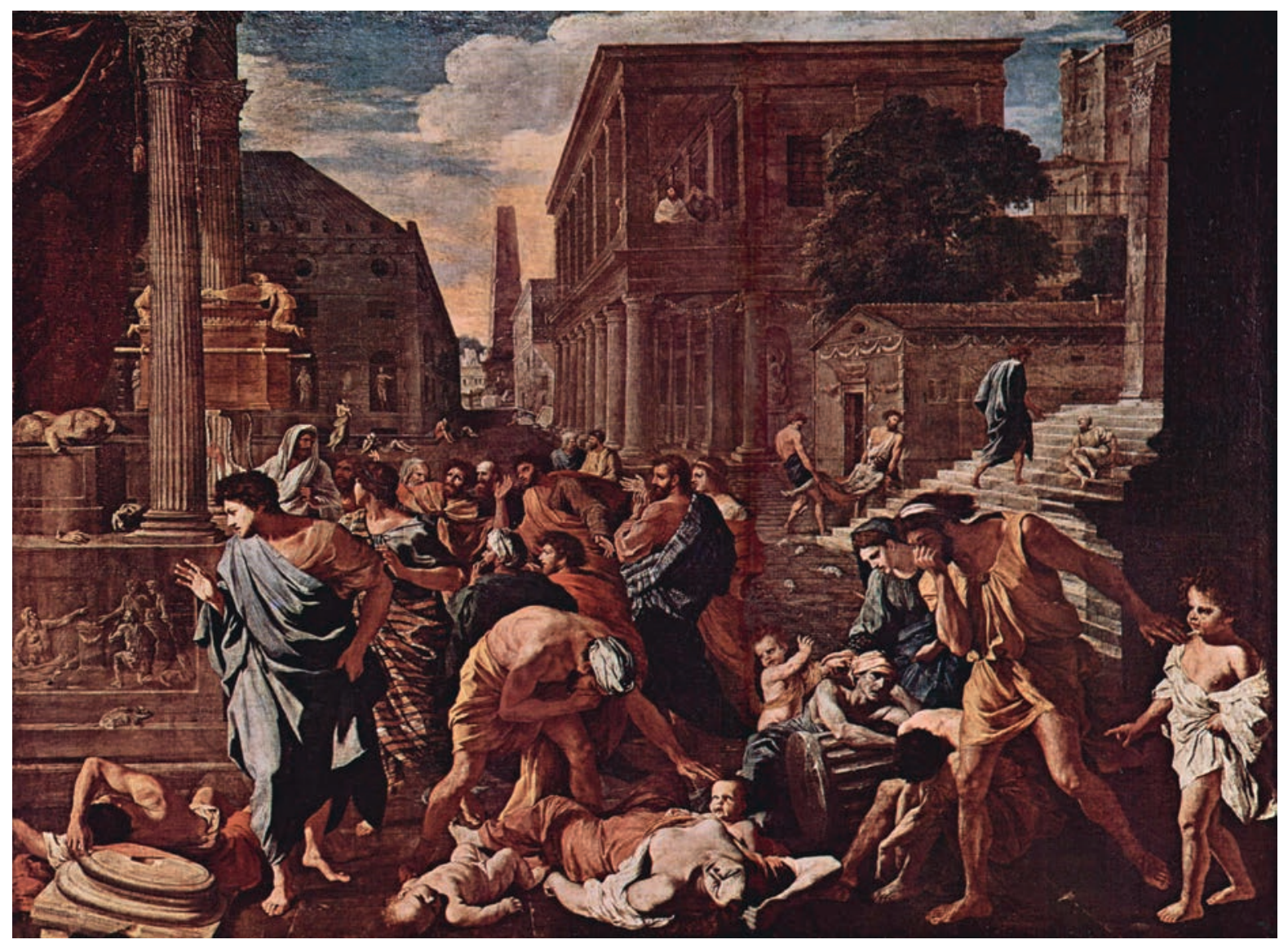

FIGURA 9. NICOLAS POUSSIN. LA PESTE DE ASHDOD, 1630. PARÍS, MUSEO DEL LOUVRE. WIKIMEDIA COMMONS. DOMINIO PÚBLICO.

Por los mismos años se pintan composiciones en las que el interés por las ruinas convive con construcciones recientes, tales son las vistas arquitectónicas de Viviano Codazzi, uno de los primeros artistas italianos del Seicento en adoptar el tipo de perspectiva arquitectónica con la que se anticipa a las vedute y caprichos de Canaletto, Carlevaris y Bellotto de la centuria siguiente. ${ }^{3 \mathrm{I}}$ Sin embargo, todavía en algunas pinturas de Codazzi se aprecia cierta impronta escenográfica en los

31. A propósito de las vedute pintadas por estos artistas, en especial por Belloto, véase entre otros trabajos publidados por Marinelli, Sergio: «I lumi neri dell'illuminista», en KowalCzYK, Bozena Anna (ed.), Bellotto e Canaletto: lo stupore e la luce. Milán, Silvana, 2016. 
fondos arquitectónicos que pinta, en obras como las dedicadas a las entradas de emperadores, realizadas en colaboración con Domenico Garciulo, valga de ejemplo la Entrada triunfal de Constantino en Roma (I636-I638) (Figura Io). En este tipo de vistas, al igual que en las realizadas por otros artistas del entorno romano especializados en arquitecturas, como Michelangelo Cerquozzi, las escenas urbanas oscilan entre el interés por la arqueología y la representación de la contemporaneidad, sin olvidar junto al estudio del aire o la luz, la rigurosa aplicación de la perspectiva lineal. ${ }^{32}$

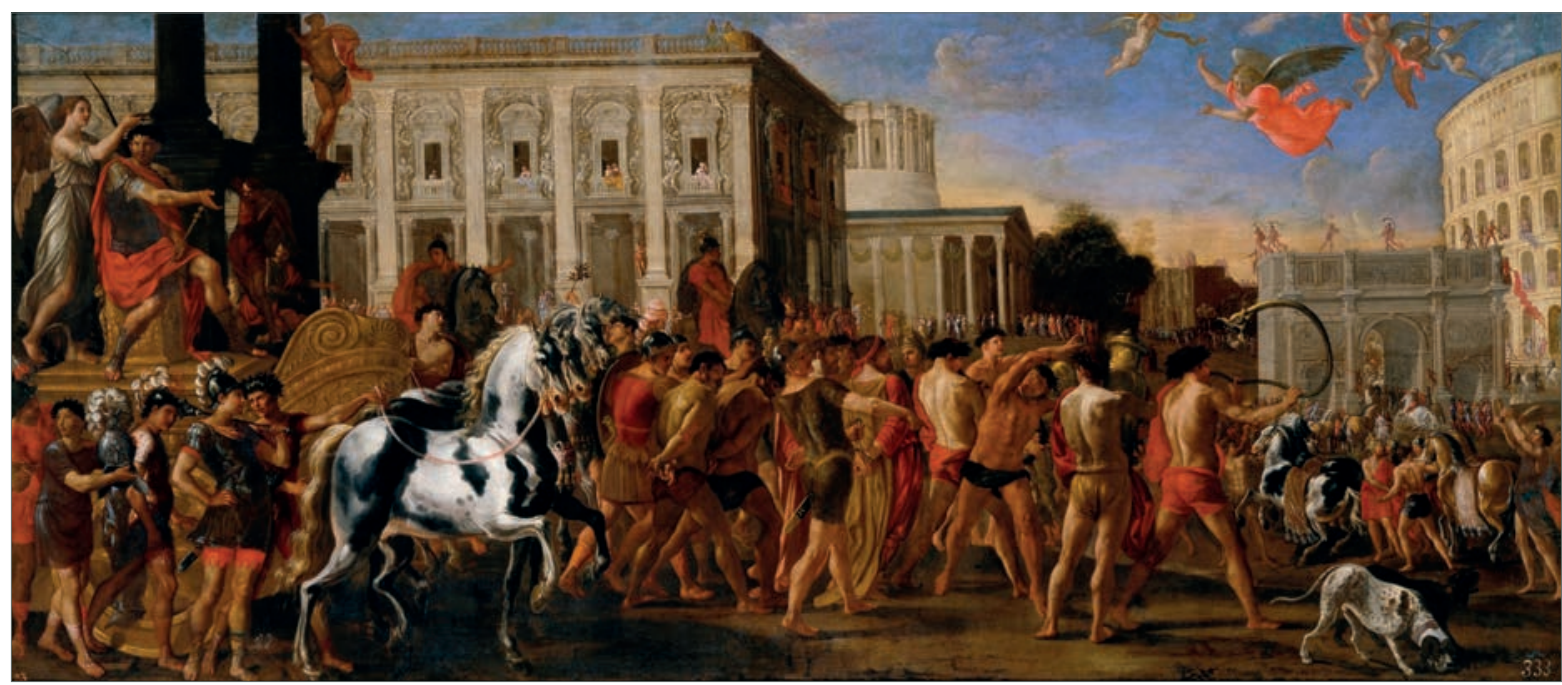

FIGURA 10. V. CODAZZI Y D. GARGIULO. ENTRADA TRIUNFAL DE CONSTANTINO EN ROMA. 1636-1638. MADRID, MUSEO NACIONAL DEL PRADO.

Mención aparte merecen las escenografías urbanas pintadas por los artistas del norte que cultivaron el nuevo género también conocido como capricho arquitectónico. Son vistas de edificios y ciudades no solo desconocidas o irreconocibles sino, incluso, imposibles. ${ }^{33}$ La perspectiva arquitectónica que, en otros contextos, constituye el telón de fondo o el escenario de la historia representada pasa en este tipo de pinturas a convertirse definitivamente en la protagonista. En la obra del holandés Hans Vredeman de Vries, en concreto en su libro Perspectiva (Leiden, 1604) aparecen modelos de plazas grandiosas, fuentes, patios, jardines, etc., recreando una suntuosa arquitectura palaciega que parece anunciar el esplendor de la escenografía barroca (Figura II). ${ }^{34}$ Se trata de vistas urbanas que simulan

32. Una excelente exposición sobre la representación de arquitecturas en la pintura fue la organizada hace unos años por el Museo Thyssen-Bornemisza y la Fundación Caja Madrid titulada Arquitecturas pintadas. Del Renacimiento al siglo XVIII (Madrid, 18 octubre de 2011 al 22 enero de 2012). La bibliografía sobre el uso de la perspectiva lineal en los pintores de la Edad Moderna es muy extensa, citaré aquí tan solo el estudio «clásico» de KEMP, Martin: «La perspectiva lineal de Rubens a Turner», en La ciencia del arte. La óptica en el arte occidental de Brunelleschi a Seurat (1990). Madrid, Akal, 2000, pp. 111-180.

33. Azara, Pedro: «Castillos en el aire, ciudades en el cielo. Arquitecturas imaginarias en el arte occidental», en La ciudad que nunca existió. Arquitecturas fantásticas en el arte occidental. Bilbao, Museo de Bellas Artes de Bilbao, 2004, pp. 13-32.

34. Veánse, entre otras aproximaciones a la obra de De Vries el completo estudio de HeUER, Christopher P.: The city rehearsed: object, architecture and prints in the worlds of Hans Vredeman de Vries. London \& New York, Routledge, 2009. 
estar dispuestas a servir de sustento a la acción de un drama.35 Pedro Azara destacó la labor de Hans Vredeman de Vries como arquitecto de grandes escenografías callejeras para el desfile de monarcas y se percató de algo que, a nuestro propósito, considero relevante:

«algunas de estas imágenes muestran edificios o ciudades que no se distinguen, justamente, de los que aparecen en los fondos teatrales. Las fachadas parecen (pintadas sobre) telones de fondo, como si detrás de ellas no hubiera nada, como si allí no se viviera». ${ }^{36}$

La influencia de $\mathrm{H}$. Vredeman de Vries se hará pronto notar en algunos grabados publicados por los hermanos Joannes y Lucas van Doetecum, cuyas perspectivas urbanas evocan algunos de los arquetipos de Serlio para las escenas trágica y cómica, un prototipo que se repite también en otros pintores del mismo contexto, desde Paul Vredeman de Vries a Dirik van Denle. De este modo lo constató Delfín Rodríguez:

\begin{abstract}
«Y muy posiblemente esa concepción escenográfica de la arquitectura, articulada en estampas entendidas como ejercicios disponibles de perspectivas, así como el valor modal y de decoro de los órdenes, procediera del modelo propuesto en la extraordinariamente influyente interpretación que Sebastiano Serlio (1474-1554) hiciera, en ambos casos, de Vitruvio. Fue precisamente en su Secondo libro dell'Architettura (1545), en el que el arquitecto y teórico boloñés, codificó gráficamente las vitruvianas scena trágica, scena comica y scena satirica, de tan decisivas consecuencias en la pintura de arquitecturas y de perspectivas y en la ordenación de la escenografía teatral del Renacimiento».37
\end{abstract}

La intrínseca relación entre arquitectura, perspectiva y ciudad que desde el Quattrocento se advierte tanto en la pintura como en el teatro, se vuelve a hacer evidente en el siglo XVIII. Es importante recordar que los más importantes pintores de vedute tuvieron formación o una actividad relevante como escenógrafos, tal fue el caso del pintor Antonio Joli, o de arquitectos tan decisivos en este período como Filippo Juvara..$^{8}$

Más de cuatro siglos después de que las primeras vistas de ciudades en perspectiva fuesen empleadas tanto en los escenarios como en la pintura, Picasso pinta para los Ballets Rusos escenografías que evocan la escena urbana de matriz renacentista. En más de una ocasión se ha indicado que el telón de obertura de Parade es la primera gran composición que realiza Picasso en su vuelta al clasicismo, pues parece respetar algunas de las convenciones mantenidas por el teatro naturalista desde que en el Renacimiento se formulasen las reglas del escenario en perspectiva. Picasso ponía

35. González-Román, Carmen: Spectacula..., p. 358-361.

36. Azara, Pedro: op. cit., p. 18. La negrita es mía.

37. Rodríguez, Delfín: «De arquitectura y ciudades pintadas. Metáforas del tiempo, del espacio y del viaje», en Arquitecturas pintadas. Del Renacimiento al siglo XVIII. Madrid, Museo Thyssen-Bornemisza, 2011, pp. 29-30. Véase también, PAUWELS, Yves: «La cultura arquitectónica y los decorados de la pintura en los siglos XVI-XVII», en Arquitecturas pintadas. Del Renacimiento al siglo XVIII. Madrid, Museo Thyssen-Bornemisza, 2011, pp. 73-86.

38. ROdRíGUEZ, Delfín: «De arquitectura y ciudades pintadas...», p. 48. Véase también, GONZÁLEZ-ROMÁN, Carmen: «Tendencias de la escenografía en el entorno goldoniano», Rivista di Letteratura Teatrale, 5, 2012, pp. 125-135. 


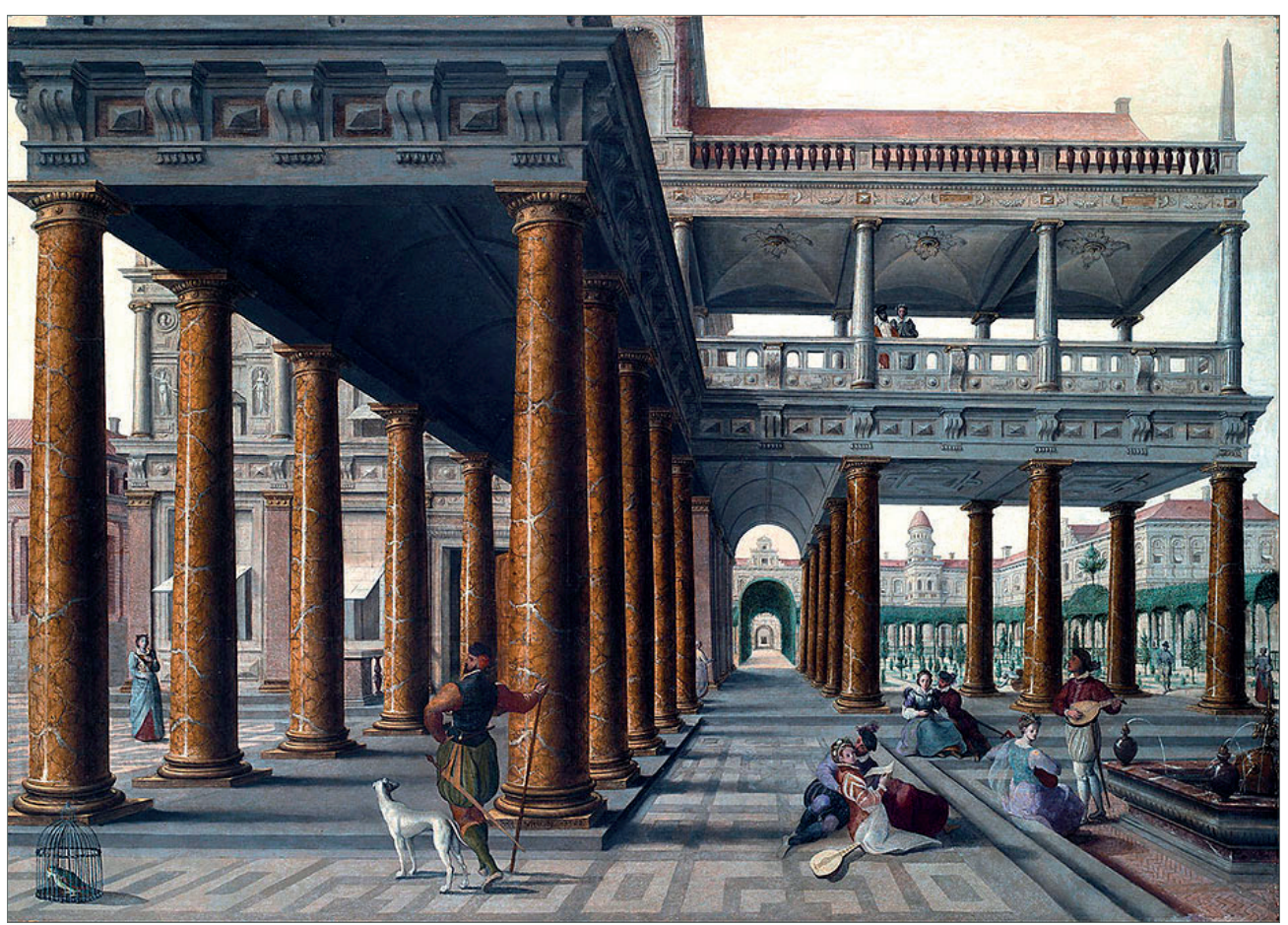

FIGURA 11. HANS VREDEMAN DE VRIES. ARQUITECTURA FANTÁSTICA CON PERSONAJES. 1654. MUSEO DE BELLAS ARTES DE BILBAO. FUENTE: WIKIMEDIA COMMONS. DOMINIO PÚBLICO.

a prueba con este telón las expectativas de un sector de público que acudía al teatro esperando, posiblemente, encontrarse con el Picasso del cubismo. Sin embargo, mientras sonaban las primeras notas, lo que los espectadores contemplaban era una escena narrativa en la que un vendedor y unos músicos miran a la niña que se balancea sobre una yegua convertida en Pegaso. ${ }^{39}$ La escena pintada por Picasso, que debía reproducir un ambiente de calle, remite a un escenario teatral, estamos en este caso ante el teatro dentro del teatro. Pero en el escenario pintado adquieren un particular protagonismo las líneas del pavimento, que insinúan un recorrido en perspectiva, con cortinas a modo de bastidores situados a ambos lados de la escena y, como fondo de toda la composición, un arco a modo de ruina clásica.

Es posible que Picasso, en su visita al Museo di San Martino en Nápoles, donde adquirió la fotografía de una escena de la commedia dell'arte que se conserva en su álbum de dibujos de $1917,{ }^{40}$ o en otra de sus visitas italianas pudiera contemplar el tipo de escenografía all'italiana que insinúa el telón de Parade. En efecto, el Museo

39. El tema se ha interpretado desde diversos puntos de vista. En general, se ha vinculado este retorno a lo clásico con el viaje que realizó Picasso a Italia para encontrarse con Diaghilev y los Ballets Rusos y ultimar los preparativos de Parade. Werner Spies relacionó el telón de Picasso con una de las Scene populari di Napoli, del pintor Achille Vianelli. En concreto, con una estampa titulada Taverna de hacia 1831, cuyos originales serían contemplados por Picasso ya que se conservan dos fotografías de dichas aguatintas en el cuaderno de 1917 que Picasso llevaba a raíz de su viaje por Italia, véase SPIES, Werner: «Parade: la pieza didáctica antinómica», en OCAÑA I GoMÃ, Mª Teresa (ed.), Picasso y el teatro. Parade, Pulcinella, Cuadro flamenco, Mercure. Barcelona, Institut de cultura de Barcelona, Museo Picasso, 1996, pp. 22-29.

40. Ibidem. 
di San Martino de Nápoles posee una sección dedicada a la historia del teatro napolitano, con diseños de escenografías, retratos, etc. Una de las piezas que pudo conocer Picasso es un óleo pintado por Michele Foschini que representa el interior del teatro de San Carlo durante la representación de un ballet a finales del XVIII. Allí mismo se conservan los diseños de escenografías de Antonio Niccolini, arquitecto y escenógrafo de la corte napolitana del settecento.

En este retorno a lo clásico, Picasso se inspira con mayor énfasis en las perspectivas ilusionistas de la escenografía renacentista cuando trabaja en los bocetos preparatorios del telón del ballet Pulcinella (1920). Los pequeños apuntes que incluye Douglas Cooper en su imprescindible libro Picasso Theatre, muestran como el artista llega a dibujar un esquema en el que las líneas de la composición fugan hacia un punto situado en el fondo de la escena. ${ }^{4 \mathrm{I}}$ En otra ocasión, los esbozos para Pulcinella ofrecen vistas en perspectiva ${ }^{42}$ que recuerdan las composiciones en ángulo con las que Galli Bibbiena revolucionó la escenografía barroca. En un dibujo a lápiz y tinta, Picasso representa parte de la sala, el arco del proscenio y, al fondo, tras un marco trapezoidal, una perspectiva con edificios a un lado y otro. ${ }^{43}$ En el telón definitivo de Pulcinella se consolidará esta disposición preliminar, situando al fondo una escena con edificios dispuestos a ambos lados de una calle y delante una serie de palcos desde los cuales, en esta ocasión, unos personajes se asoman dirigiendo sus gestos y miradas hacia nosotros. ${ }^{44}$ Todo el conjunto queda enmarcado por un arco de proscenio clásico. $\mathrm{Al}$ pintar un telón dentro de un telón, el artista genera una inquietante ambigüedad espacial, al tiempo que propicia un singular juego de miradas que integran al espectador en el espacio de la representación. Tal es el efecto provocado por esta sugerente metaescenografía.

\section{LA PERSPECTIVA URBANA: UNA IMAGEN «SUPERVIVIENTE»}

Resultaría inabarcable en este espacio aludir a todas aquellas creaciones de las vanguardias del siglo XX en las que se recrea, sugiere, reproduce, altera o destruye el prototipo de escenario compuesto por una perspectiva urbana. No es ese, ni ha sido hasta ahora, el propósito de este artículo. Bastaría, sin embargo, mencionar a modo de ejemplo los paisajes metafísicos de Giorgio de Chirico, o la anteriormente citada obra de Delvaux, en cuyos surreales y sintéticos escenarios se rememora la escenográfica disposición de la arquitectura. Cabría aludir también, como precursor de este tipo de imágenes sintéticas de la ciudad, al pintor simbolista belga Leon Spilliaert y obras como Galeries royales d'Ostende (1908), ${ }^{45}$ donde la arquitectura situa-

\footnotetext{
41. CoOper, Douglas: Picasso Theatre, New York, Harry N. Abrams, 1987, figura 267.

42. Idem, figura 268.

43. Idem, figura 249 .

44. Véase un detalle de uno de los dibujos preparatorios del telón final en la siguiente web: <https:// csosoundsandstories.org/pulcinella-stravinskys-discovery-of-the-past/> [Consulta: 20-4-2019].

45. Véase esta obra y otros cuadros similares del artista en la web: Musées Royaux des Beaux-Arts de Belgique: <https://www.fine-arts-museum.be/fr/la-collection/leon-spilliaert-galeries-royales-d-ostende?letter=s\&artist=spilliaertleon-1> [Consulta: 20-4-2019].
} 
da a un lado de la composición dibuja un pronunciado escorzo hasta fundirse en el horizonte con el paisaje.

Toda esta, si se me permite, «tradición escenográfica» quiero suponer que viene dada por las imágenes de vistas urbanas en perspectiva usadas en el teatro y en las artes visuales desde el Renacimiento italiano, las cuales han venido siendo fijadas culturalmente. Pero también, qué duda cabe, debemos relacionar el uso de esta particular iconografía con un determinado modo de visión que incluso en las primeras fotografías del siglo XIX siguió siendo proyectivo, estático y monofocal. No es casual, como advirtió Juan Antonio Ramírez, que las primeras fotografías fuesen vistas urbanas tomadas desde una ventana, «como si estuviera latiendo en ellas aquella idea de la pirámide visual seccionada por una apertura rectangular transparente (un velo), que tanto encandiló a los teóricos renacentistas». ${ }^{46}$ Una construcción visual que descubrimos también en el cine e incluso, más recientemente, con afán hiperrealista, en videojuegos como Assassin's Creed II.

Visto desde otro ángulo, la simulación de un espacio urbano en perspectiva como fondo de una obra plástica constituye el punto de partida para la negación de dicha convención figurativa. Esta es la actitud sostenida por algunos artistas de vanguardia, allí donde la lógica y la aplicación del procedimiento geométrico que genera la ilusión de profundidad es sustituida por la idea o la imagen simbólica de ella. De este modo podríamos interpretar el fotomontaje de Paul Citroën, Metrópoli (1923), ${ }^{47}$ un verdadero compendio de calles y edificios en los que destacan los hitos arquitectónicos de diferentes ciudades. Alfredo Aracil y Delfín Rodríguez sostenían a propósito de los fotomontajes de temática similar creados por Citroën que «la permanencia de la ciudad tradicional viene anunciada con la presencia de edificios de carácter representativo, de fuertes connotaciones simbólicas e ideológicas y apoyados en el prestigio cultural de los códigos clásicos»..$^{48}$ Pese a que las escalas y las perspectivas se confunden y se anulan pretendidamente, estas imágenes recortadas por Citröen de diferentes paisajes urbanos las podemos llegar a reconstruir y ordenar en nuestra imaginación sin mucho esfuerzo. En un análisis general de la apariencia formal de las obras pictóricas de vanguardia se advierte, en este sentido, dos tipos de acercamiento a la representación en perspectiva. De un lado, a través de la negación de la misma y, de otro, la destrucción del espacio ilusionista desde un respeto aparente de las formas que pretende en última instancia cuestionar, aún más si cabe, el valor de la representación. ${ }^{49}$

Se trate de reminiscencias, o de una invocación, estamos hablando en estos casos de la pervivencia o remanencia, más o menos consciente, de una imagen. A propósito de esta cuestión, no puedo dejar de mencionar aquellos conceptos que tanto han

\footnotetext{
46. Ramírez, Juan Antonio: El objeto y el aura. (Des)orden visual del arte moderno. Madrid, Akal, 2009, p. 17.

47. Véase una reproducción fotográfica del collage original en la web del MOMA NY: <https://www.moma.org/ interactives/objectphoto/objects/83984.htm/> [Consulta: 20-4-2019].

48. Aracil, Alfredo \& Rodríguez, Delfín: El siglo XX: entre la muerte del arte y el arte moderno. Madrid, Akal, 1998 , p. 131.

49. Martínez Silvente, Ma Jesús: «La perspectiva como superviviente de la tradición clásica: De la arquitectura de las formas a la perspectiva del ombligo», en GonzÁlez-Román, Carmen (ed.) A través de la mirada. Anatomía, arquitectura y perspectiva en la tradición artística occidental. Madrid, Abada, 2014, p. 270.
} 
aportado a la noción de tiempo en la historia del artey, en especial, al análisis cultural de la imagen. Me refiero a las aportaciones del ya citado Didi Huberman, ${ }^{50}$ pero también Mieke Bal ${ }^{5 \mathrm{y}} \mathrm{y}$, más recientemente, A. Nagel y Ch. S. Wood,,$^{52} \mathrm{y}$ a sus respectivos análisis en torno a la «supervivencia», «cita» $\mathrm{y}$ «anacronismo» de las imágenes que, en cualquiera de sus despliegues argumentativos y aplicaciones concretas, valdrían para situar el análisis de las obras que vengo mencionando:

«[la forma superviviente] no sobrevive triunfalmente a la muerte de sus concurrentes. Muy al contrario, sobrevive, sintomática y fantasmalmente, a su propia muerte: desapareciendo en un momento dado de la historia, reapareciendo más tarde en un momento en que quizás ya no se la esperaba y habiendo sobrevivido, en consecuencia, en los limbos todavía mal definidos de una «memoria colectiva». ${ }^{53}$

Si con Las Bellas errantes de Delvaux comenzábamos hablando de «supervivencia», por lo que supone de «reaparición» de la scena tragica de Serlio, merece la pena detenerse, para finalizar, en la obra de Marx Ernst 2 niños amenazados por un ruiseñor (I924). ${ }^{54}$ Definida por el propio artista como «la última consecuencia de sus primeros collages», muestra sobre una superficie pintada varias piezas de madera. La perspectiva acelerada que va desde la casita en relieve, construida en plano frontal sobre el soporte pictórico en dirección al arco monumental pintado al fondo evoca, nuevamente, la escena serliana. La combinación de lo construido y lo pintado ¿podría interpretarse como una imagen «superviviente» de los edificios dispuestos en relieve que Serlio situaba a ambos lados del escenario en combinación con la perspectiva pintada al fondo? En cualquier caso, este collage de Ernst nos permite situar conceptualmente la obra en un ámbito de estudio a explorar, el de las metaescenografías pintadas en el arte contemporáneo.

50. Didi-Huberman, George: Ante la imagen. Pregunta formulada a los fines de una historia del arte (1990). Murcia, CENDEAC, 2010; Ante el tiempo. Historia del arte y anacronismo de las imágenes (2000), Buenos Aires, Adriana Hidalgo, 2006; La imagen superviviente. Historia del arte y tiempo de los fantasmas según Aby Warburg (2002), Madrid, Abada, 2013.

51. BAL, Mieke: Quoting Caravaggio: Contemporary Art, Preposterous History. Chicago, Chicago University Press, 1999.

52. NAGEL, Alexandre \& WOOD, Chistopher S.: Renacimiento anacronista (2010). Madrid, Akal, 2017.

53. Didi-HubERmAN, George. La imagen superviviente..., op. cit., p. 60.

54. Véase la obra y la ficha técnica en la web del MOMA NY: <https://www.moma.org/collection/works/79293> [consulta: 18 abril 2019]. 


\section{BIBLIOGRAFIA}

Alivert, Maria Inés: Una scena di città attribuita a Sebastiano Serlio: breve saggio di iconología teatrale. Pisa, ETS, 2008.

Aracil, Alfredo \& Rodríguez, Delfín: El siglo XX: entre la muerte del arte y el arte moderno. Madrid, Akal, i998.

Azara, Pedro: «Castillos en el aire, ciudades en el cielo. Arquitecturas imaginarias en el arte occidental», en La ciudad que nunca existió. Arquitecturas fantásticas en el arte occidental. Bilbao, Museo de Bellas Artes de Bilbao, 2004, pp. 13-32.

BAL, Mieke: Quoting Caravaggio: Contemporary Art, Preposterous History. Chicago, Chicago University Press, I999.

Belting, Hans: Florencia y Bagdad. Una historia de la mirada entre Oriente y Occidente. Madrid, Akal, 2012.

Beltramini, Guido: «Andrea Palladio I508-I580», en Beltramini, Guido \& Burns, Howard (eds.): Palladio. Venezia, Marsilio Editore, 2008.

BÉrCHEz, Joaquín: El Greco. Architeto de retablos. Madrid, Instituto Cervantes, 2014.

BONET CORREA, Antonio: «La perspectiva, el territorio y la escenografía renacentista en Maquiavelo», Boletín de Arte, 25 (2014), pp. 27-4I.

Boschini, Marco: Le ricche minere della pittura veneziana (I664). Venezia, Francesco Nicolini, I674. Disponible en: <https://archive.org/details/lericchemineredeoobosc/page/n7> [Consulta: I9-4-20I9].

Camerota, Filippo: La prospettiva del Rinascimento. Arte, architettura, scienza. Milán, Mondadori Electa, 2006.

Cooper, Douglas: Picasso Theatre, New York, Harry N. Abrams, 1987.

DAmisch, Hubert: «Figuras de la desenvoltura», en DAmisch, Hubert: El origen de la perspectiva. Madrid, Alianza, I997, pp. I67-196.

Didi-Huberman, George: Ante la imagen. Pregunta formulada a los fines de una historia del arte (I990). Murcia, CENDEAC, 2010.

Didi-Huberman, George: Ante el tiempo. Historia del arte y anacronismo de las imágenes (2000), Buenos Aires, Adriana Hidalgo, 2006.

Didi-Huberman, George: La imagen superviviente. Historia del arte y tiempo de los fantasmas según Aby Warburg (2002), Madrid, Abada, 2013.

FALOMIR, Miguel: «El Greco y la pintura veneciana», Archivo secreto. Revista cultural de Toledo, 6 (2015), pp. 253-262.

FALOMir, Miguel: Una obra maestra restaurada. El Lavatorio de Jacopo Tintoretto. Madrid, Museo Nacional del Prado, 2000.

FAlomir, Miguel: Tintoretto. Museo Nacional del Prado, El Viso, 2007.

GonzÁlez-Román, Carmen: Spectacula. Teoría, Arte y Escena en la Europa del Renacimiento. Málaga, Universidad de Málaga, 20oI.

GonzÁlez-Román, Carmen: «Escenografías a la italiana en la corte de Felipe II», Goya, 33I, 20I0, pp. 99-I09.

GonzÁlez-Román, Carmen: «Tendencias de la escenografía en el entorno goldoniano», Rivista di Letteratura Teatrale, 5, 20I2, pp. I25-I35.

GonzÁlez-Román, Carmen: «Más de ‘opiniones y paradojas'. El Greco y las ideas en torno a la arquitectura en la España de su época», en Almarcha, Esther \& alt.: El Greco en su IV 
Centenario: patrimonio hispánico y diálogo intercultural. Toledo, Universidad de CastillaLa Mancha, 2016, pp. 425-444.

GonZÁlez-Román, Carmen (ed.) A través de la mirada. Anatomía, arquitectura y perspectiva en la tradición artística occidental. Madrid, Abada, 2014.

GonZÁlezZ-Román, Carmen \& Solís, Isabel: «Reconstructing the image of the ideal city in Renaissance painting and theatre: Its influence in specific urban environments. Digital technology and visual culture», en GAGo, Alexandra \& alt. (eds.): Cities in the Digital Age: Exploring Past, Present and Future. Lisboa, CITCEM, 2019, pp. 29-45.

Gould, Cecil: «Sebastiano Serlio and Venetian Painting». Journal of the Warburg and Courtauld Institutes, 25 (1962), 56-64.

Grosso, Marsel y Guidarelli, Gianmario: Tintoretto e lárchitettura. Venezia, Marsilio, 2018.

HEUER, Christopher P.: The city rehearsed: object, architecture and prints in the worlds of Hans Vredeman de Vries. Londres y Nueva York, Routledge, 2009.

Kemp, Martin: «La perspectiva lineal de Rubens a Turner», en La ciencia del arte. La óptica en el arte occidental de Brunelleschi a Seurat (I990). Madrid, Akal, 2000, pp. III-I80.

MARINELli, Sergio: «l lumi neri dell' illuminista», en KowalCzyK, Bozena Anna (ed.), Bellotto e Canaletto: lo stupore e la luce. Milán, Silvana, 2016.

MARTíneZ SiLvente, $M^{a}$ Jesús: «La perspectiva como superviviente de la tradición clásica: De la arquitectura de las formas a la perspectiva del ombligo», en GonZÁlez-Román, Carmen (ed.) A través de la mirada. Anatomía, arquitectura y perspectiva en la tradición artística occidental. Madrid, Abada, 20I4, pp. 269-280.

Marías, Fernando \& Bustamante, Agustín: Las ideas artísticas de El Greco. Madrid, Cátedra, I98I.

MERINo Peral, Esther: El reino de la ilusión: Breve historia y tipos de espectáculo, el arte efímero y los orígenes de la escenografía. Universidad de Alcalá, 2006.

Molina Folx, Vicente: Tintoretto y los escritores. Madrid, Galaxia Gutemberg, Museo Nacional del Prado, 2007.

NAGEL, Alexandre \& Wood, Chistopher S.: Renacimiento anacronista (2010). Madrid, Akal, 2017.

PAUWELS, Yves: «La cultura arquitectónica y los decorados de la pintura en los siglos XVIXVII», en Arquitecturas pintadas. Del Renacimiento al siglo XVIII. Madrid, Museo ThyssenBornemisza, 20II, pp. 73-86.

Pavón Maldonado, Basilio: «El Greco arquitecto», Archivo Español de Arte, 35, 1962, pp. 209-220.

Portús, Javier: Metapintura. Un viaje a la idea del arte en España. Madrid, Museo Nacional del Prado, 2016.

RAMírEZ, Juan Antonio: El objeto y el aura. (Des)orden visual del arte moderno. Madrid, Akal, 2009.

Ridolfi, Carlo: Vita de Giacopo Robusti detto il Tintoretto... Venecia, Guglielmo Oddoni, I642, p. 88. Disponible en: <https://ia6oI2oI.us.archive.org/6/items/bub_gb_QDz4so7NkjAC/ bub_gb_QDz4so7NkjAC.pdf> [Consulta: 19-4-2019].

RoDRíguez, Delfín: «De arquitectura y ciudades pintadas. Metáforas del tiempo, del espacio y del viaje», en Arquitecturas pintadas. Del Renacimiento al siglo XVIII. Madrid, Museo Thyssen-Bornemisza, 20II, pp. 19-52.

Rosand, David: «Theater and Structure in the Art of Paolo Veronese», en Rosand, David: Painting in Cinquecento Venice. Titian, Veronese, Tintoretto. New Haven, Yale University Press, I982.

RufFInI, Franco: Commedia e festa nel rinascimento. La Alandria alla corte di Urbino. Bologna, Il Mulino, I986. 
SPIES, Werner: «Parade: la pieza didáctica antinómica», en OcAÑA I Gomà, Ma Teresa (ed.), Picasso y el teatro. Parade, Pulcinella, Cuadro flamenco, Mercure. Barcelona, Institut de cultura de Barcelona, Museo Picasso, I996, pp. 22-29.

Sтоісніта, Victor: La invención el cuadro. Arte, artífices y artificios en los orígenes de la pintura europea (1993). Barcelona, Ediciones del Serbal, 2000.

TAMBURINI, Elena: Il quadro della visione. Arcoscenico e altri sguardi ai primordi del teatro moderno. Roma, Bulzoni, 2004.

Wethey, Harold Edwin: El Greco and his School. Princeton, Princeton University Press, I962.

ZoRzı, Ludovico: Il teatro e la città. Torino, Einaudi, I977. 



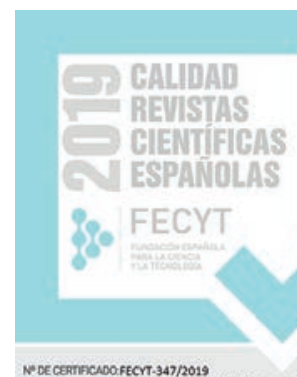

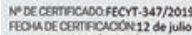

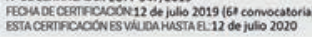

\section{SERIE VII HISTORIA DEL ARTE}

REVISTA DE LA FACULTAD DE GEOGRAFÍA E HISTORIA
AÑO 2019

NUEVA ÉPOCA

ISSN: $1130-4715$

E-ISSN 2340-1478

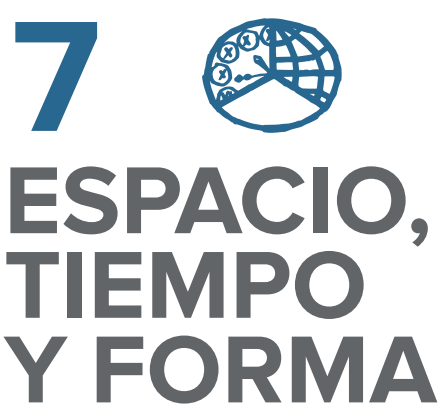

Dossier per Filippo Camerota: L'Apelle Vitruviano: Riflessioni sulla cultura architettonica dei pittori nella prima età moderna - El Apelles vitruviano: Reflexiones en torno a la cultura arquitectónica de los pintores de la Edad Moderna

17 FILIPPO CAMEROTA (GUEST EDITOR)

Introduzione. La prospettiva come tema vitruviano · Introduction.

Perspective as a Vitruvian Theme

4.1 Francesco P. Di TeOdoro (GUest author)

Due quæstiones vitruviane riconosciute: la base attica e il capitello composito nel terzo libro del De prospectiva pingendi di Piero della Francesca e un plagio conclamato di Luca Pacioli . Two Recognized Vitruvian Problems: The Attic Base and the Composite Capital in the Third Book of De Prospectiva Pingendi by Piero della Francesca and an Evident Plagiarism by Luca Pacioli

65 GIOVANNI MARIA FARA (GUEST AUTHOR) and Vitruvius

77 CARMEn GONZÁlez-RomÁn

Metaescenografías pintadas · Painted Meta-scenographies

103 SARA FuENTES LÁZARo

Ad vitandam confusionem. Una aproximación analítica al tratado sobre perspectiva de Andrea Pozzo . Ad vitandam confusionem. An Analytical Approach to Andrea Pozzo's Treatise on Perspective

\section{Miscelánea · Miscellany}

133 ANTONIO PÉREZ LARGACHA

Art in Egypt. Ritual, Sense and Function

Predynastic

161 Alejandra IzQuierdo Perales

contexto de los templos ptolemaicos. The Temple of Hathor in Deir el-Medina: An Iconographic Study in the Context of the Ptolemaic Temples

191 JaIme Moraleda Moraleda

The Work of Miniatures for the Book of Vows of the City Hall of Toledo
209 Sergio Ramírez González, antonio Bravo nieto \& Juan ANTONIO BELLVER GARRIDO

La recuperación de dos repuestos de pólvora del siglo XVIII en Melilla: análisis y restauración - Recovery of Two Spare Gunpowder Warehouses from the XVIII ${ }^{\text {th }}$ Century in Melilla: Analysis and Restoration

231 Alejandro de LA Fuente Escribano

expresión del romanticismo en España . The Restoration of Guadamur Castle in the XIX $X^{\text {th }}$ Century as an Expression of Romanticism in Spain

26 Paula Gabriela núñez, Carolina lema, Carolina Michel \& MAIA VARGAS

La construcción estatal patagónica en el siglo XIX. El dibujo como arte científico $€$ institucional . The Patagonian State Construction in XIX ${ }^{\text {th }}$ Century. The Drawing as Scientific and Institutional Art

\section{Guillermo Juberías Gracia} la zarzuela Pan y Toros (1864) en las colecciones municipales de Madrid · A Nineteenth-Century Vision of Charles IV Spain: Designs for the Zarzuela Pan $y$ Toros (1864) in the Municipal Collections of Madrid

311 Aurora Fernández Polanco

Ojos curiosos y capital: sobre el turismo visual decimonónico · Curious Eyes and Capital: About Nineteenth-Century Visual Tourism

327 AngÉlica García-Manso

Los cinematógrafos diseñados por Fernando Perianes: una lectura Movie-theaters Planned by Fernando Perianes: A Heritage Reading around Leisure Architecture in the Province of Cáceres (Spain)

361 José-Carlos Delgado Gómez

y el médico y caricaturista José Delgado Úbeda «Zas» . The Humoristic Halls' during the Spanish Postwar Period (1940-1953) and the Doctor and Caricaturist José Delgado Úbeda «Zas»

379 IOANNIS MOURATIDIS

The Space Dimension of «Being A Museum User»: Reflections on the Social Construction of an Inclusive Exhibition Space

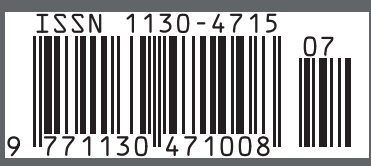


AÑO 2019

NUEVA ÉPOCA

ISSN: 1130-4715

E-ISSN 2340-1478

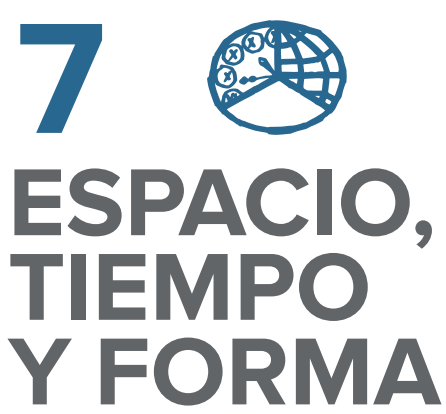

Reseñas · Book Reviews

4.07 Julia Fernández Toledano arte y la política en los tiempos del telón de acero. Madrid, Brumaria, 2019

\subsection{M. ${ }^{a}$ Cristina Hernández Castelló}

Leonardo da Vinci. Munich, Himer Publishers, 2018

\section{Francisco ORTS-RUIZ}

Mínguez, Víctor (dir.), El linaje del rey monje. La configuración cultural e iconográfica de la Corona aragonensis (1164-1516). Castelló de la Plana, Publicacions de la Universitat Jaume I, 2018. 